\title{
MEASUREMENT OF ETHANOL SUBSIDIES AND ASSOCIATED ECONOMIC DISTORTIONS: AN ANALYSIS OF BRAZILIAN AND U.S. POLICIES
}

\author{
Mario de Queiroz Monteiro Jales * \\ Cinthia Cabral da Costa ${ }^{\dagger}$
}

\begin{abstract}
Resumo
Este estudo tem por objetivos medir os valores dos subsídios equivalentes das políticas de apoio ao etanol nos Estados Unidos e no Brasil e estimar a magnitude das distorções econômicas por eles causadas. Para o período entre 2002 e 2011, os valores anuais médios destes subsídios foram de US $\$ 7,2$ bilhões nos Estados Unidos e US $\$ 2,1$ bilhões no Brasil. As políticas brasileiras elevaram o preço mundial em média em $2,7 \%$ neste período, elevando a produção nos dois países $(1,2 \%$ nos Estados Unidos e 5,3\% no Brasil), reduzindo o consumo norte-americano em 4,7\% e expandindo o consumo brasileiro em 16,1\%. Já as políticas dos Estados Unidos deprimiram o preço mundial em média em 2,4\% no mesmo período, expandindo o consumo nos dois países (2,5\% no Estados Unidos e 1,3\% no Brasil), aumentando a produção norte-americana em $8,3 \%$, mas provocando uma queda de 4,7\% na produção brasileira. Em 2012, ambos países mudaram suas políticas, mas as distorções no mercado permanecem.
\end{abstract}

Palavras-chave: Etanol; Subsídio; Tarifa de importação; Biocombustíveis.

\section{Abstract}

The objectives of this study were to measure the subsidy equivalent value of ethanol policies in the United States and Brazil, and estimate the magnitude of associated economic distortions. For 2002-11, average annual ethanol subsidy levels were US $\$ 7.2$ billion in the United States and US $\$ 2.1$ billion in Brazil. Brazilian support measures for ethanol increased the world price by $2.7 \%$ on average in this period, which expanded output in both countries (1.2\% in the United States and $5.3 \%$ in Brazil), reduced U.S. consumption by $4.7 \%$ and increased Brazilian consumption by $16.1 \%$. On the other hand, U.S. ethanol policies depressed world prices by $2.4 \%$ on average in the same period, which boosted consumption in both countries (by $2.5 \%$ in the United States and $1.3 \%$ in Brazil), expanded U.S. production by $8.3 \%$, but reduced Brazilian output by $4.7 \%$. Although both countries changed their policies in 2012, distortions remain.

Keywords: Ethanol; Subsidy; Import tariff; Biofuels.

JEL classification: F13, Q17, Q18, Q41, Q42, Q48.

DOI: http : / dx.doi .org/10.1590/1413-8050/ea375

\footnotetext{
* Ph.D., Charles H. Dyson School of Applied Economics and Management, Cornell University. E-mail: mdj29@cornell.edu

${ }^{\dagger}$ Researcher at Embrapa. E-mail: cinthia.cabral.da.costa@gmail.com
} 


\section{Introduction}

Alternative transportation fuels with a lower carbon imprint have been at the center of the debate on global warming and the need to mitigate atmospheric concentrations of greenhouse gases. Biofuels stand out in this discussion for their renewable nature and potential to reduce carbon dioxide equivalent emissions. As a number of countries have adopted policies to encourage the development of biofuel markets, biofuel use has expanded significantly in recent years. World consumption of fuel ethanol, the most widely used biofuel, increased from 20 billion liters in 2002 to 80 billion liters in 2012 (LMC 2013). The United States and Brazil, the world's largest producers and consumers of fuel ethanol, accounted for approximately $85 \%$ of global production and consumption in 2012 (LMC 2013). The ethanol market support policies adopted in these two countries have significantly impacted producers or consumers of motor fuels.

This study has two main objectives. First, to assess the subsidy equivalent value of policies that affect ethanol supply and demand in Brazil and the United States. Second, to estimate the size of the distortions caused by these policies. The concept of subsidy equivalent corresponds to the monetary value of all transfers from consumers and taxpayers that affect production, consumption, income, trade or the environment. This measure is based on the indicators of support used by the Organization for Economic Cooperation and Development (OECD) to monitor and evaluate developments in agricultural policy, establish a common basis for policy dialogue among countries, and provide economic data to assess the effectiveness and efficiency of policies (OECD 2008). The study focuses on the period following the deregulation of the Brazilian sugarcane industry (2002-12).

This paper is divided into four sections in addition to this introduction. Section 2 analyzes U.S. and Brazilian policies that affect the ethanol sector and develops a methodology to estimate the monetary value of these measures. Section 3 discusses subsidy equivalent estimates for the two countries under analysis. Section 4 assesses the magnitude of the market distortions caused by U.S. and Brazilian ethanol policies. It evaluates the impact of support measures on ethanol prices, supply and demand in the United States and Brazil. Finally, Section 5 draws conclusions and addresses the implications of past and current policies.

\section{U.S. and Brazilian ethanol policies}

This section develops a theoretical model to estimate the subsidy equivalent value of U.S. and Brazilian public policy measures that support their respective ethanol sectors. Brazilian policies for hydrous and anhydrous ethanol are examined separately.

\subsection{U.S. ethanol policies}

The promotion of domestic ethanol production in the United States is intended to reduce the nation's dependence on imported fossil fuels, support the income of domestic agricultural producers, and curtail emissions of greenhouse gases that contribute to global warming and climate change. The U.S. federal government sought to achieve these goals through a combination of 
four main policy instruments in 2002-12: (i) subsidies on feedstock used in the production of ethanol (mainly corn); (ii) a tax credit for blended ethanol; (iii) a mandate establishing a minimum volume of renewable fuel that must be blended with conventional transportation fuels sold or offered for sale in the United States, and (iv) tariffs and other charges on imported ethanol. ${ }^{1}$ These measures were not always consistent with declared U.S. biofuel policy goals. For example, while the import tariff on ethanol supported U.S. farmers' income, it did not contribute to the reduction of greenhouse gas emissions, as it barred the entry of foreign sugarcane ethanol, which has a lower carbon imprint than domestic ethanol produced from corn.

Figure 1 represents corn supply and demand curves in the United States. The shaded area delimited by the rectangle $a b c d$ identifies the total subsidy on domestic corn production $\left(G_{c o r n}^{u s}\right)$; the area aefd identifies the portion of this total subsidy that corresponds to the corn used in ethanol production $\left(G_{1}^{u s}\right)$.

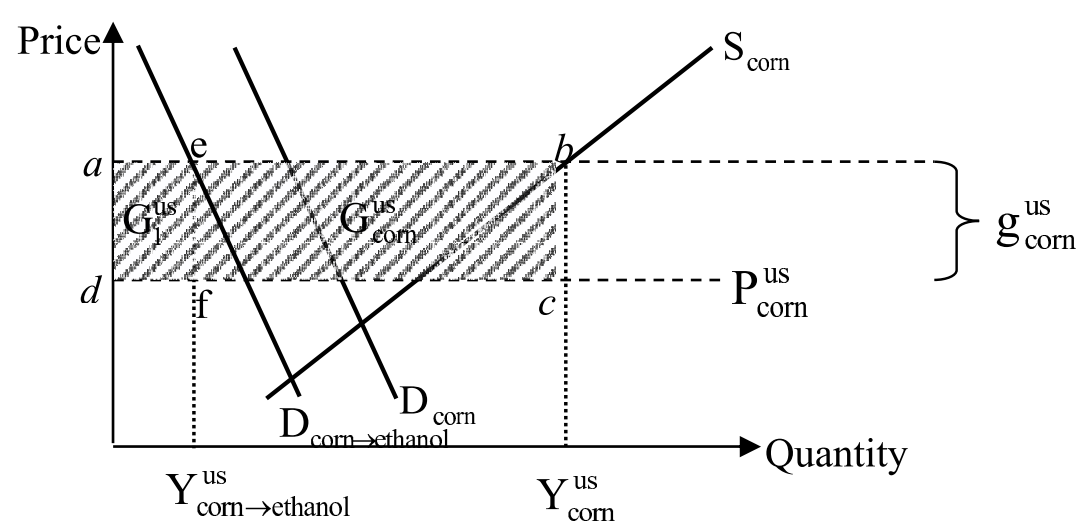

Notes: $G_{c o r n}^{u s}$ is the total value of corn production subsidies in the United States; $G_{1}^{u s}$ is the portion of total corn subsidies that directly benefits the U.S. ethanol sector; $g_{c o r n}^{u S}$ is the unit value of U.S. corn subsidies; $P_{c o r n}^{u S}$ is the U.S. domestic price of corn; $Y_{c o r n}^{u S}$ is the volume of corn produced in the United States; $Y_{c o r n \rightarrow e t h a n o l}^{u s}$ is the volume of corn used in the production of ethanol in the United States; $D_{\text {corn }}$ is corn demand; $D_{\text {corn }} \rightarrow$ ethanol is demand for corn to produce ethanol; $S_{\text {corn }}$ and is corn supply.

Source: Authors.

Figure 1: Supply and demand curves for corn in the U.S. and corresponding subsidy equivalent measures

The contribution of corn production subsidies to the ethanol production chain is obtained by multiplying the value of total corn subsidies by the fraction of total domestic corn production that is used in ethanol production. Algebraically, this is given by equation 1 . The data required to estimate $G_{1}^{u s}$ are presented in Table 1.

$$
G_{1}^{u s}=G_{c o r n}^{u s} *\left(\frac{Y_{c o r n \rightarrow e t h a n o l}^{u s}}{Y_{\text {corn }}^{u s}}\right)
$$

The mandate and the tax credit increase the demand for ethanol and lead to higher ethanol domestic prices. On the other hand, border barriers ensure a domestic price above the international price and reduce the demand for

\footnotetext{
${ }^{1}$ In addition, state governments provided a combination of subsidies, producer incentives and renewable fuel standards.
} 
ethanol. The blender - an intermediary between the producer and the end consumer - mixes ethanol and gasoline in a proportion established in the mandate and distributes the blended fuel to filling stations. The ethanol that the blender adds to gasoline was eligible for either a tax exemption or a tax credit until 2011. ${ }^{2}$ The value of the tax exemption/credit was US $\$ 0.54$ per gallon between 1990 and 2004, US $\$ 0.51$ per gallon between 2005 and early 2009, and US $\$ 0.45$ per gallon between 2009 and 2011. In order to prevent foreign producers from benefiting from this tax credit, the United States applied an import charge of US\$0.54 per gallon of ethanol, ${ }^{3}$ in addition to an ad valorem import tariff of $2.5 \%$ of the import value. While the tax credit and the specific import charge were eliminated in 2012, but the ad valorem import tariff remained in place.

Table 1: U.S. subsidies to corn used in ethanol production, 2002-12

\begin{tabular}{llllll}
\hline Year & $\begin{array}{l}\text { Corn } \\
\text { production } \\
\left(Y_{\text {com }}^{\text {us }}\right)\end{array}$ & $\begin{array}{l}\text { Corn used in } \\
\text { ethanol } \\
\text { production } \\
\left(Y_{\text {com } \rightarrow \text { ethanol }}^{\text {us }}\right.\end{array}$ & $\begin{array}{l}\text { Domestic } \\
\text { support to corn } \\
\text { production } \\
\left(G_{\text {com }}^{\text {us }}\right)\end{array}$ & $\begin{array}{l}\text { Ethanol } \\
\text { production } \\
\text { from corn }\left(Y^{u s}\right)\end{array}$ & $\begin{array}{l}\text { Ethanol CIF } \\
\text { import unit } \\
\text { value }\left(P_{i m p}^{u s}\right)\end{array}$ \\
\hline \multicolumn{2}{c}{ Million tons } & Million tons & Million US\$ & Million liters & US\$/liter \\
\hline 2002 & 227.7 & 25.3 & 2,498 & 8,102 & 0.36 \\
2003 & 256.2 & 29.6 & 3,440 & 10,617 & 0.30 \\
2004 & 299.9 & 33.6 & 5,309 & 12,888 & 0.32 \\
2005 & 282.3 & 40.7 & 10,139 & 14,781 & 0.46 \\
2006 & 267.6 & 53.8 & 5,797 & 18,491 & 0.63 \\
2007 & 332.1 & 77.5 & 3,806 & 24,687 & 0.55 \\
2008 & 307.4 & 93.4 & 4,194 & 35,240 & 0.62 \\
2009 & 333.0 & 116.0 & 3,779 & 41,407 & 0.56 \\
2010 & 316.2 & 127.5 & 3,495 & 50,342 & 0.75 \\
2011 & 313.9 & 127.3 & 4,634 & 52,805 & 0.85 \\
2012 & 272.4 & 114.3 & 2,702 & 47,420 & 0.78 \\
\hline
\end{tabular}

Sources: Fapri (2013), USDA (2013a,b), USITC (2013), WTO (2013).

By itself, the blenders' tax credit may not benefit domestic ethanol producers. If the tax credit resulted in a lower final price for blended fuel, this would increase the demand for both ethanol and gasoline, since the final product in the U.S. market is a blend of both fuels. The imposition of the import charge on ethanol prevents this from happening as it raises the domestic price of ethanol and ensures a producer price that is higher than the import price. It is the import charge, and not the tax credit per se, that assists ethanol domestic production.

The subsidy equivalent value derived from the tax credit $\left(G_{2}^{u s}\right)$ corresponds to the product of the tax credit unit value $\left(T^{u s}\right)$ and domestic ethanol production volume $\left(Y^{u s}\right)$. This is illustrated in Figure 2 by the area ghij and expressed algebraically by equation 2 :

$$
G_{2}^{u s}=Y^{u s} * T^{u s}
$$

For the years in which the United States was a net importer of ethanol (2002-2009), the subsidy equivalent value derived from import barriers corre-

\footnotetext{
${ }^{2}$ The American Jobs Creation Act of 2004 changed the mechanism of the ethanol subsidy from an excise tax exemption to a blender tax credit (Tyner 2008).

${ }^{3}$ This import charge was originally designed to offset the ethanol excise tax exemption of US\$0.54 per gallon.
} 
sponds to the product of the total volume of ethanol produced in the United States and the difference between the domestic price and the price of imported ethanol. This value is illustrated in Figure 2 by the area $i j k l$ and is expressed algebraically by equation 3 :

$$
G_{3}^{u s}=Y^{u s} *\left(P^{u s}-P_{i m p}^{u s}\right)
$$

The blending mandate is incorporated in the model only through the volume of ethanol produced domestically. This policy increases demand and helps determine the volume of ethanol produced in the United States. The total value of U.S. subsidies to the ethanol production chain $\left(G^{u s}\right)$ is given by the sum of the areas defined by adfe in Figure 1 and ghij and ijkl in Figure 2. Algebraically, it corresponds to the sum of $G_{1}^{u s}, G_{2}^{u s}$ and $G_{3}^{u s}$.

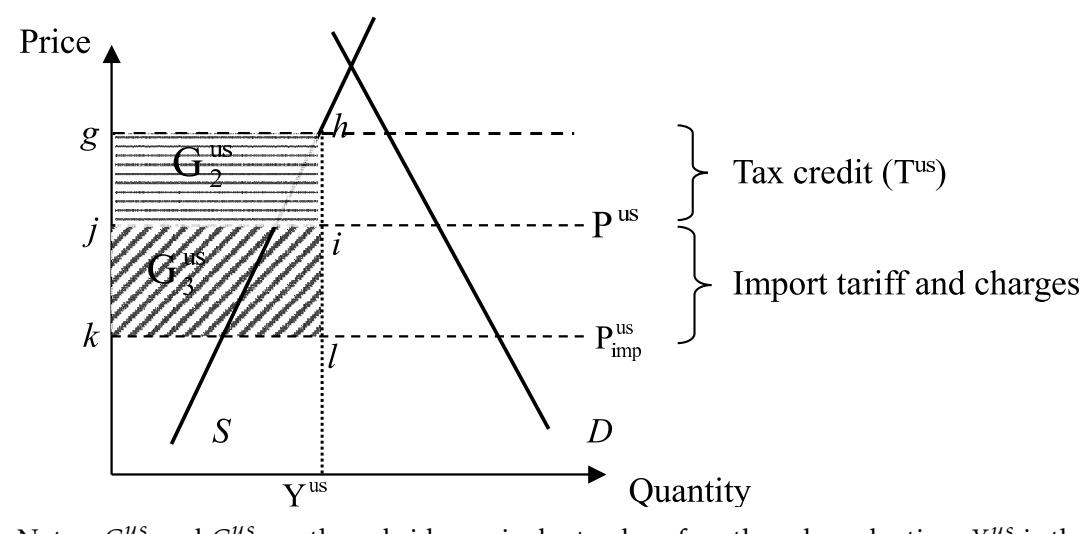

Notes: $G_{2}^{u s}$ and $G_{3}^{u s}$ are the subsidy equivalent values for ethanol production; $Y^{u s}$ is the volume of ethanol produced domestically; $P^{u s}$ is the domestic price of ethanol; and $P_{i m p}^{u s}$ is the ethanol import price to the United States. $D$ is demand and $S$ is supply. Source: Authors.

Figure 2: Supply and demand curves for U.S. ethanol market and corresponding subsidy equivalent measures

\subsection{Brazilian hydrous ethanol policies}

There are two types of ethanol used as transportation fuel in Brazil: (i) anhydrous ethanol, which is blended into gasoline; and (ii) hydrous ethanol, which is used alone in automobiles with specially designed engines. In this context, Brazil's support to the ethanol industry had three main components in the period analyzed: (i) a mandatory blending of anhydrous ethanol into gasoline, (ii) a lower tax rate for hydrous ethanol than for gasoline (i.e. differential tax rate), and (iii) another policy that, recently, has had a great effect on the ethanol market is the control exerted by the Brazilian government over the price of gasoline. Since most Brazilian producers can switch production between the two types of ethanol, the differential tax rate on hydrous ethanol also indirectly impacts anhydrous ethanol production.

The competition between hydrous ethanol and gasoline occurs daily at the filling station since the Brazilian automotive industry created the flexible internal combustion engine, capable of running on hydrous ethanol, a blend of gasoline with anhydrous ethanol, or any arbitrary combination of the two. 
The first commercial flexible fuel vehicle capable of running on any blend of gasoline and ethanol was launched in early 2003. Since then, flexible fuel cars have led sales of new automobiles and have rapidly changed the profile of Brazil's automobile fleet. Figure 3 illustrates the change in the composition of the fleet, by fuel type, between 2003 and 2012 .

The competition between gasoline and hydrous ethanol in Brazil has intensified with the growth in the fleet of flexible fuel automobiles (Costa \& Guilhoto (2011)). However, some competition between these two fuels already existed prior to the advent of flexible fuel engines, as they were preceded by engines that ran exclusively on hydrous ethanol. ${ }^{4}$ From the 1980 s until 2003, Brazilian consumers chose between gasoline and hydrous ethanol when they decided on the type of automobile to buy at the dealer. Since 2003, Brazilians, who have flex fuel vehicles, have been able to choose between gasoline and hydrous ethanol every time they fill up at the pump.

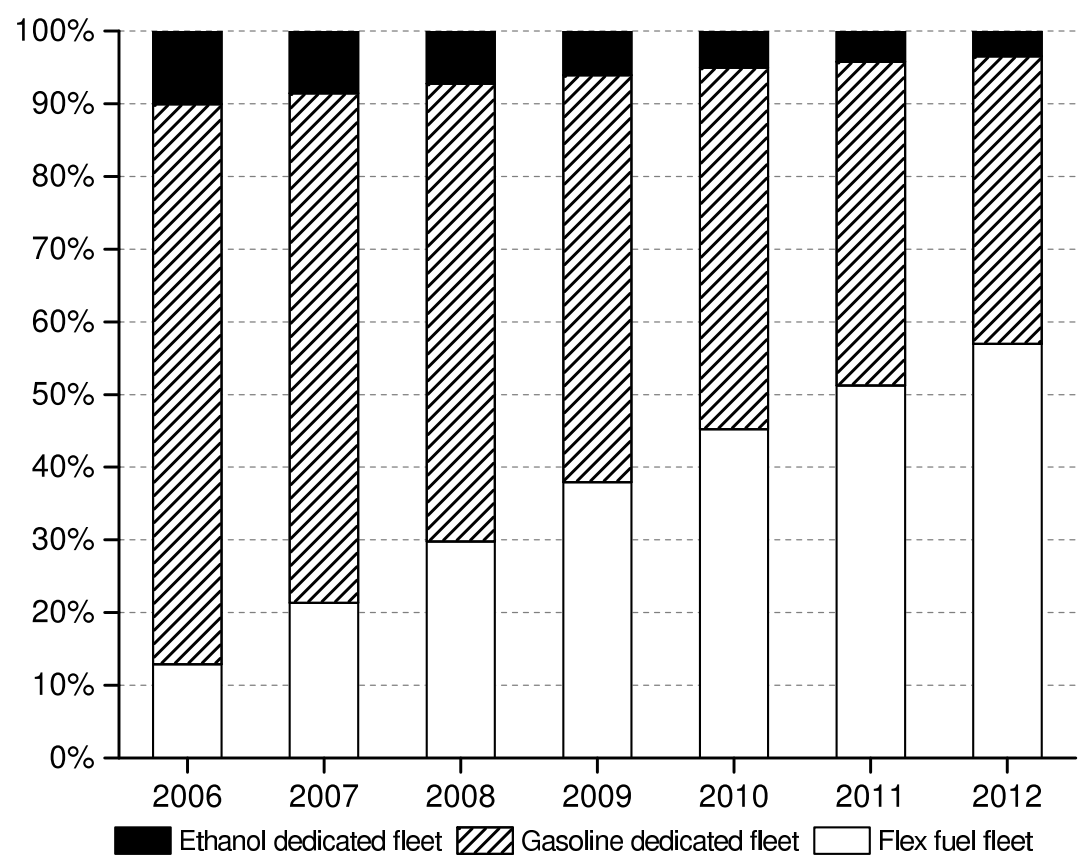

Source: UNICA (2013b).

Figure 3: Brazilian fleet of vehicles (Otto cycle), by fuel type, 2006-12

After the deregulation of the Brazilian sugar-ethanol sector in the late 1990s, the federal government has stimulated the consumption of hydrous ethanol at the expense of gasoline C (a mixture of $75-80 \%$ gasoline and 20 $25 \%$ anhydrous ethanol) through the difference in final price paid by the consumer. This policy is implemented by the imposition of a higher tax burden on gasoline $\mathrm{C}$ as compared to hydrous ethanol.

There are four main taxes on transportation fuels in Brazil: (i) the Contribution from the Intervention on the Economic Domain (CIDE), (ii) the Con-

\footnotetext{
${ }^{4}$ One key difference between the U.S. and Brazilian ethanol markets is that ethanol and gasoline are direct substitutes at the point of sale in Brazil. In the United States, ethanol is generally blended with gasoline at $10 \%$. Higher ethanol blends correspond to trivial shares of total transportation fuel consumption.
} 
tribution to the Program of Social Integration (PIS), (iii) the Contribution to the Financing of Social Security (COFINS), and (iv) the Tax on the Circulation of Goods and Services (ICMS). While the first three are federal taxes, the third is a state tax. Given the weight of the ICMS, the overall tax burden must be calculated individually for each state. Furthermore, while the CIDE tax is payable only on gasoline C, the PIS, COFINS and ICMS taxes are payable on both gasoline $\mathrm{C}$ and hydrous ethanol.

The CIDE tax rate was $\mathrm{R} \$ 0.28$ per liter in $2002-07, \mathrm{R} \$ 0.18$ per liter in $2008, R \$ 0.23$ per liter in $2009-10, R \$ 0.15$ per liter in 2011 , and $R \$ 0.09$ per liter between January and June 2012, when it was finally eliminated (Brazilian Ministry of Finance (2013)). The PIS/COFINS tax rate remained around $9.25 \%$ in the period 2002-12. The prices of transportation fuels and the ICMS tax rates differ from state to state. Average ICMS rates ${ }^{5}$ and consumption levels for ethanol and gasoline in each Brazilian state in 2002-12 are shown in Figures 4 and 5 .

A third Brazilian policy that affects ethanol markets consists of governmentcontrolled gasoline prices. Figure 6 shows the difference between annual average domestic and international gasoline prices between 2002 and 2012. Domestic prices were moderately higher than international prices between 2002 and 2009. This difference became more significant in 2010, when domestic prices were on average $30 \%$ higher than international prices, encouraging the consumption of hydrous ethanol in place of fossil fuels. The opposite occurred in 2012, when domestic gasoline prices were substantially lower than world prices, discouraging the consumption of hydrous ethanol. Since small differences between domestic and international prices may be explained by variations in the exchange rate, the subsidy equivalent value of governmentcontrolled gasoline prices is estimated only when the difference between domestic and international prices is greater than $10 \%$ (this occurred only in 2010 and 2012).

As illustrated in Figure 7 (a), the subsidy equivalent unit value for hydrous ethanol in Brazil is equivalent to the difference between the producer price (i.e., $P_{h y d}^{b r}-T_{h y d}^{b r}$ ) and the price that producers would otherwise receive if hydrous ethanol were treated in the same way as gasoline C (i.e., $P_{h y d}^{b r}-$ $\left.P_{\text {hyd }}^{b r} *\left(T_{\text {gas }}^{b r} / P_{\text {gas }}^{b r}\right)\right)$. This metric reflects both tax differentials in favor of hydrous ethanol and gasoline price controls. After algebraic manipulations, the subsidy equivalent unit value $\left(g_{h y d}^{b r}\right)$ is given by equation 4 :

$$
g_{\text {hyd }}^{b r}=P_{h y d}^{b r} *\left(\left(\frac{T_{g a s}^{b r}}{P_{\text {gas }}^{b r}}\right)-\left(\frac{T_{h y d}^{b r}}{P_{h y d}^{b r}}\right)\right)
$$

\footnotetext{
${ }^{5}$ While several Brazilian states adopt a standard formula by which the ICMS tax is the product of the ICMS rate and the price paid by the consumer, some states adopt an alternative approach in which the ICMS tax corresponds to the product of the ICMS rate and an official estimated price. This alternative ICMS tax does not vary with the real price of the purchased product, but with an estimated price that can vary significantly over time and from state to state. Since it would be very onerous to collect the necessary data to calculate the ICMS tax by the alternative method, in this study, the ICMS taxes of all states are calculated according to the standard methodology. Therefore, the effective ICMS rate for states that adopt the alternative method may be higher or lower than the values calculated in this study, given that the effective consumer price may be lower or higher than the official estimated price.
} 


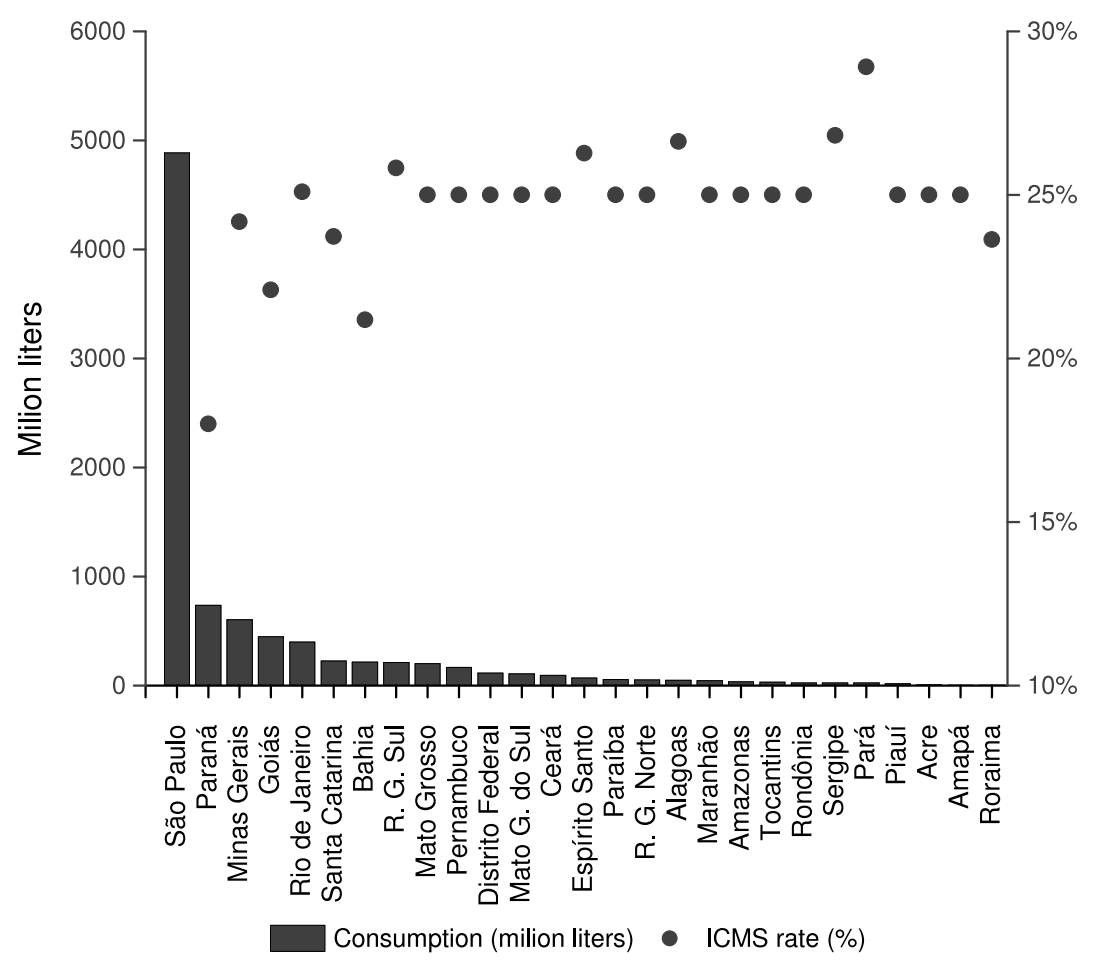

Source: ANP $(2013 b, a)$, State Secretariats of Finance (2013) and UNICA (2013a).

Figure 4: Average annual hydrous ethanol consumption and ICMS rate, by Brazilian state, 2002-12

where $T_{\text {gas }}^{b r}$ and $T_{\text {hyd }}^{b r}$ are the total tax burdens on gasoline $\mathrm{C}$ and hydrous ethanol, respectively; and $P_{g a s}^{b r}$ and $P_{h y d}^{b r}$ are the consumer prices for gasoline $\mathrm{C}$ and hydrous ethanol, respectively. $T_{g a s}^{b r}$ also includes the difference between the government-controlled domestic gasoline price and the world gasoline price when the absolute value of the difference between their annual averages is greater than $10 \%$ (which occurred in 2010 and 2012).

The subsidy equivalent for hydrous ethanol production in Brazil $\left(G_{h y d}^{b r}\right)$ corresponds to the product of the above subsidy unit value and the volume of hydrous ethanol consumed in Brazil $\left(D_{h y d}^{b r}\right)$. This is illustrated in Figure 7 (a) as the area delimited by the letters mnop, which is expressed algebraically by equation 5:

$$
G_{h y d}^{b r}=g_{h y d}^{b r} * D_{h y d}^{b r}
$$

Consumption volumes are used because only the amount of hydrous ethanol consumed domestically benefits from the differential in taxation (or equivalent taxation in the case of government-controlled gasoline prices $\left.{ }^{6}\right)$. In contrast, production volumes are used in the calculation of ethanol subsidy equivalent values in the United States because policies in this country protect domestic producer prices by means of import barriers.

\footnotetext{
${ }^{6}$ This equivalent taxation corresponds to the difference between the government-controlled domestic gasoline price and the world gasoline price over the world gasoline price.
} 


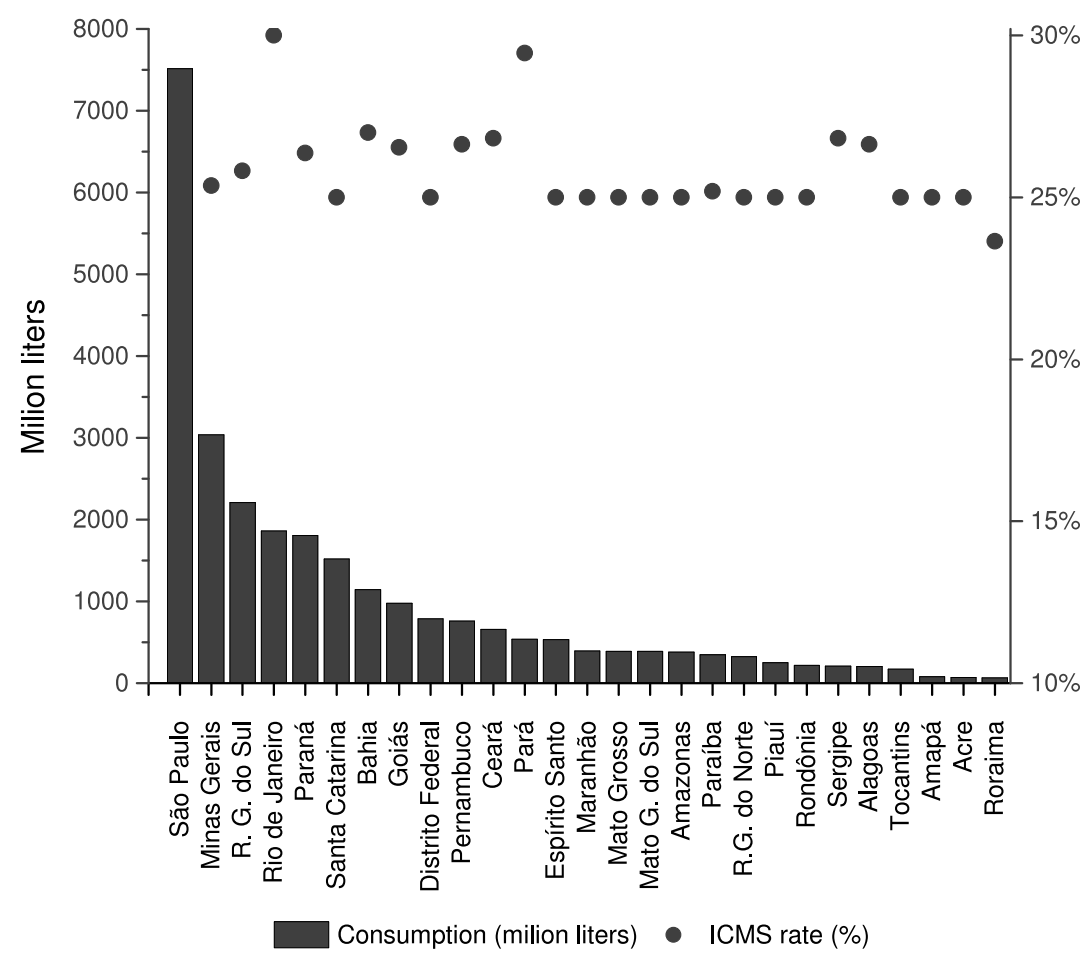

Source: ANP $(2013 b, a)$, State Secretariats of Finance (2013) and UNICA (2013a).

Figure 5: Average annual anhydrous ethanol consumption and ICMS rate, by Brazilian state, 2002-12

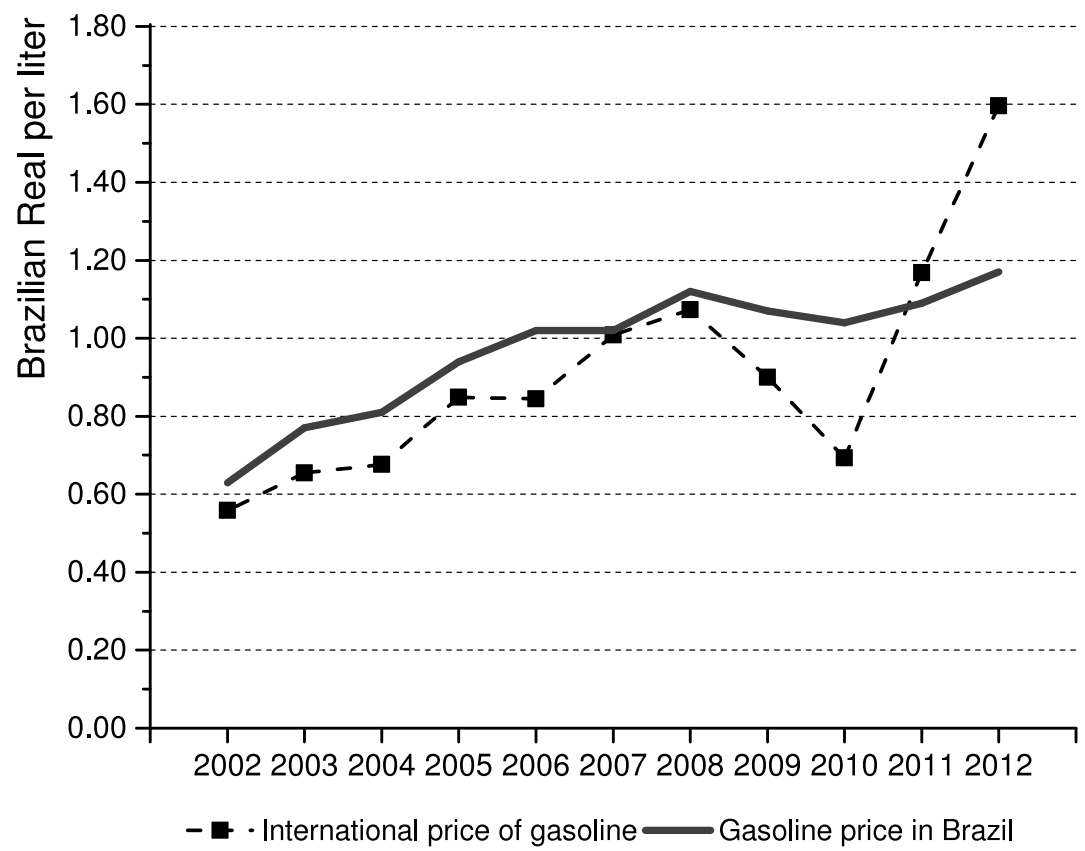

Source: MDIC (2013), FAO (2013) and ANP (2013a).

Figure 6: Price behavior of gasoline in the international market and in Brazil, 2002-12 
(a)

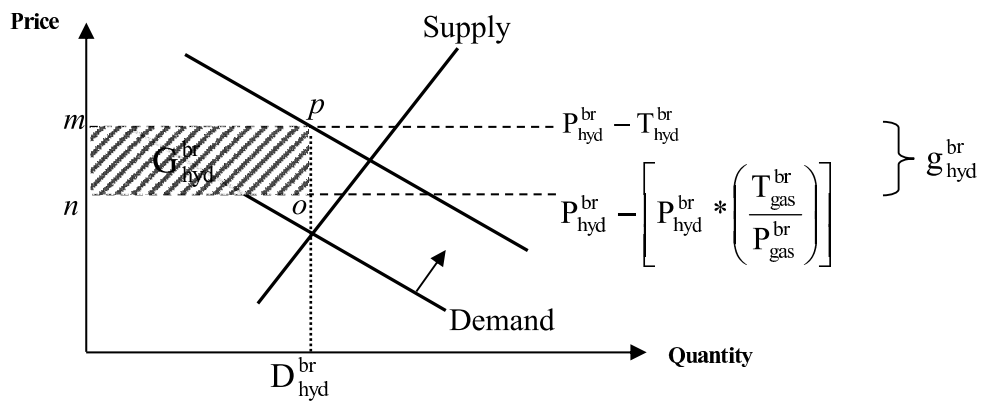

(b)

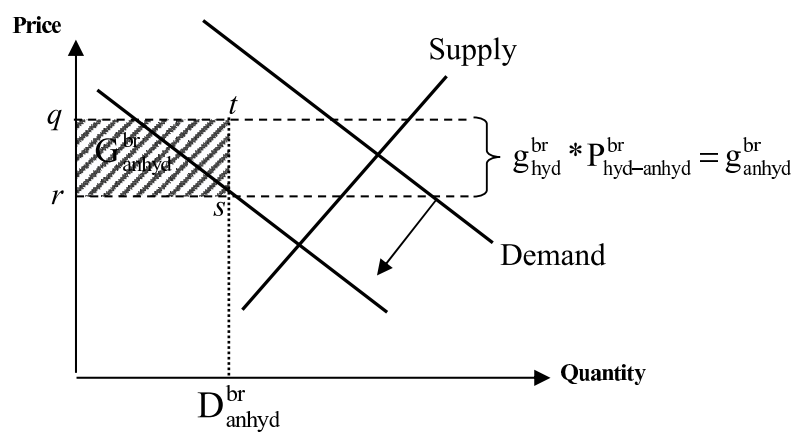

Notes: $G_{h y d}^{b r}$ is the subsidy equivalent value for hydrous ethanol in Brazil; $P_{h y d}^{b r}$ is the hydrous ethanol consumer price; $T_{h y d}^{b r}$ is the hydrous ethanol tax burden; $T_{\text {gas }}^{b r}$ is the gasoline C tax burden; $P_{g a s}^{b r}$ is the gasoline C consumer price; $g_{h y d}^{b r}$ is the unit value of hydrous ethanol subsidies; $G_{a n h y d}^{b r}$ is the value of total anhydrous ethanol subsidies; $P_{h y d-a n h y d}^{b r}$ is the relative producer price of anhydrous ethanol expressed in terms of hydrous ethanol; and $D_{h y d}^{b r}$ and $D_{a n h y d}^{b r}$ are consumption volumes for hydrous and anhydrous ethanol, respectively.

Source: Authors.

Figure 7: Supply and demand curves for (a) hydrous ethanol and (b) anhydrous ethanol in Brazil and corresponding subsidy equivalent measures

\subsection{Brazilian anhydrous ethanol policies}

The only direct incentive given by the Brazilian government to the production of anhydrous ethanol consists in the mandate that determines that a specific amount of ethanol must be mixed into gasoline. While in the United States the mandate establishes the total volume of ethanol that must be mixed with gasoline in a given year, in Brazil the mandate defines a percentage of ethanol that must be present in gasoline C. In Brazil, as in the United States, the blending mandate is incorporated into the present model through the total volume of ethanol used nationally in gasoline $\mathrm{C}$.

The anhydrous ethanol market is also indirectly affected by the differential tax rate in favor of hydrous ethanol. Figure 7 illustrates the relationship between the subsidy equivalent values for hydrous and anhydrous ethanol. As the tax on gasoline $\mathrm{C}$ increases, the demand for gasoline $\mathrm{C}$ decreases and the demand for hydrous ethanol increases. Since gasoline and anhydrous ethanol are sold in fixed proportion, the demand for the latter also decreases.

The subsidy equivalent unit value corresponds to the difference between 
the observed price and the price that should prevail in the absence of the aforementioned shifts in demand. The price of anhydrous ethanol must follow the price of hydrous ethanol since they have the same inputs and similar production processes. Moreover, production can easily be switched between the two types of ethanol. If the price of anhydrous ethanol were at a level that permitted higher profits than those on hydrous ethanol, producers would supply more of the former and less of the latter. This adjustment in the supply of each product would in turn cause a reduction in the price of anhydrous ethanol and a rise in the price of hydrous ethanol.

The subsidy equivalent for anhydrous ethanol production in Brazil $\left(G_{a n h y d}^{b r}\right)$, represented in Figure 7 (b) by the area of the rectangle qrst, and given by equation 6 , is the product of the volume of anhydrous ethanol consumed domestically $\left(D_{a n h y d}^{b r}\right)$, the hydrous ethanol subsidy unit value $\left(g_{h y d}^{b r}\right)$ given by equation 4 , and the relative producer price of anhydrous ethanol expressed in terms of hydrous ethanol $\left(P_{\text {anhyd-hyd }}^{b r}\right)$ :

$$
G_{\text {anhyd }}^{b r}=g_{\text {hyd }}^{b r} * P_{\text {anhyd-hyd }}^{b r} * D_{\text {anhyd }}^{b r}
$$

Producer prices are only available for the state of São Paulo. Since São Paulo accounted for between 50 and $60 \%$ of total Brazilian ethanol production in 2002-12, producer prices in this state are used as a proxy for the entire country. The relative price of anhydrous ethanol expressed in terms of hydrous ethanol varied between 1.13 and 1.17 in the same period.

The subsidy equivalent value for ethanol in Brazil $\left(G^{b r}\right)$ corresponds to the sum of the areas circumscribed by mnop and qrst in Figure 7. Algebraically, it is the sum of the subsidy equivalents summarized in equations 5 and 6 . While the subsidy equivalent value for U.S. ethanol is based on production volumes (equation 3), the subsidy equivalent value for Brazilian ethanol is calculated with reference to consumption volumes (equations 5 and 6). As described in Section 2.4, this difference stems from the fact that U.S. policies support domestic production, while Brazilian policies support the consumption of ethanol irrespective of its origin.

\subsection{Classification of policies}

Ethanol support policies can be divided into three categories, according to their main beneficiaries: (a) subsidies to domestic ethanol production, which benefit domestic producers at the expense of producers in other countries; (b) subsidies to ethanol production to the detriment of gasoline, which do not discriminate between domestic output and imports, and (c) subsidies to ethanol consumption to the detriment of gasoline. Consumption subsidies also benefit ethanol production, given that output must increase in order to meet the strengthened demand.

The main difference between category (a) and categories (b) and (c) is that the last two do not make a distinction between domestic and foreign ethanol. Subsidies in category (a), on the other hand, create trade distortions as they discriminate against imports.

Table 2 compares the key characteristics of ethanol policies adopted in the United States and Brazil. Mandates to blend ethanol into gasoline are applied by both countries. This policy instrument shifts the ethanol demand curve to the right and raises the price of ethanol. This subsidy is paid by 
consumers when they purchase blended gasoline at the pump. The impact of blending mandates on the price of ethanol is not measured directly, as one cannot observe the prices that would prevail in the absence of such incentives. Nonetheless, mandates affect subsidy equivalent values because they influence the consumption and production volumes used in equations 2, 3, 5 and $6 .^{7}$ Since blending mandates do not differentiate between domestic and imported ethanol, they constitute subsidies to ethanol production to the detriment of gasoline, or category (b) above.

As U.S. corn production subsidies and ethanol import barriers encourage domestic ethanol production at the expense of imports, they are classified under category (a). Since ethanol tax credits favor ethanol production at the expense of gasoline, but do not discriminate between domestic and imported ethanol, they are classified under category (c).

Until 2011, Brazilian ethanol policies aimed at reducing gasoline consumption by favoring the adoption of renewable fuels, with equal treatment of domestic and foreign ethanol. Since the application of different tax rates to gasoline and hydrous ethanol reduced the relative price of the latter, the tax differential constituted an ethanol consumption subsidy to the detriment of gasoline (category (c)). Starting in 2012, the focus of Brazilian transportation fuel policies has been the control of inflation. As a result, domestic gasoline prices were kept artificially low, which created disincentives for hydrous ethanol consumption.

\section{Subsidy equivalent estimates}

U.S. and Brazilian ethanol subsidy equivalent values in the 2002-12 period are presented in Table 3. Columns (i), (ii) and (iii) list the subsidy equivalent derived from corn production subsidies, tax credit and ethanol import barriers in the United States, which are calculated by equations 1, 2 and 3, respectively. The total subsidy equivalent for the ethanol production chain in the United States is summarized in column (iv). Columns (v) and (vi) list the subsidy equivalent derived from the Brazilian differential tax rate for hydrous ethanol and gasoline and its indirect impact on the anhydrous ethanol market, which are given by equations 5 and 6 , respectively. The total subsidy equivalent in Brazil is listed in column (vii). For each of the eleven years under analysis, the subsidy equivalent to ethanol production in the United States was significantly higher than in Brazil. On average, the subsidy equivalent in Brazil corresponded to less than a quarter of the value in the United States.

Owing to the significant decline observed in U.S. and Brazilian policies for ethanol in 2012, we first describe and analyze the period 2002-11 and then the year 2012 .

The subsidy equivalent value of ethanol-related policies in the United States increased from US $\$ 2.6$ billion in 2002 to US $\$ 12.7$ billion in 2009 . About $46 \%$ of this support came from the import tariff and $40 \%$ from the tax credit in 2002-2009. Tax credits became the dominant source of subsidies in 2010 and 2011, as the United States became a net exporter of ethanol and no market price support was recorded. Finally prorated feedstock subsidies accounted for the entirety of the total subsidy equivalent after ethanol tax credits were

\footnotetext{
${ }^{7}$ In the United States, economic incentives may cause ethanol demand to exceed the minimum volumes established by mandates.
} 
Table 2: Qualitative evaluation of U.S. and Brazilian ethanol policies

\begin{tabular}{|c|c|c|c|c|}
\hline $\begin{array}{l}\text { Policy } \\
\text { (i) }\end{array}$ & $\begin{array}{l}\text { Who pays the } \\
\text { subsidy? } \\
\text { (ii) }\end{array}$ & $\begin{array}{l}\text { Wedge between domes- } \\
\text { tic and import prices? } \\
\text { (iii) }\end{array}$ & $\begin{array}{l}\text { Affects ethanol demand? } \\
\text { (iv) }\end{array}$ & $\begin{array}{l}\text { Subsidy for what? } \\
\text { (v) }\end{array}$ \\
\hline \multicolumn{5}{|c|}{ UNITED STATES } \\
\hline Blending mandate & Consumer & No & Yes & Ethanol production to the detriment of gasoline (b) \\
\hline Corn production subsidy & Taxpayer & No & No & Domestic ethanol production to the detriment of imports (a) \\
\hline Ethanol tax credit & Consumer & No & Yes & Ethanol consumption to the detriment of gasoline (c) \\
\hline Ethanol import tariff & Consumer & Yes & No & Domestic ethanol production to the detriment of imports (a) \\
\hline \multicolumn{5}{|c|}{ BRAZIL } \\
\hline Blending mandate & Consumer & No & Yes & Ethanol production to the detriment of gasoline (b) \\
\hline $\begin{array}{l}\text { Tax differential favoring } \\
\text { hydrous ethanol* }\end{array}$ & Consumer & No & Yes & Ethanol consumption to the detriment of gasoline (c) \\
\hline $\begin{array}{l}\text { Impact of previous policy } \\
\text { on anhydrous ethanol }\end{array}$ & Consumer & No & Yes & Ethanol consumption to the detriment of gasoline (c) \\
\hline
\end{tabular}


Table 3: Subsidy equivalent value, U.S. and Brazilian ethanol sectors, 200212 (million US\$)

\begin{tabular}{|c|c|c|c|c|c|c|c|}
\hline & \multicolumn{4}{|c|}{ United States } & \multicolumn{3}{|c|}{ Brazil } \\
\hline & $\begin{array}{l}\text { Corn Pro- } \\
\text { duction } \\
\text { Subsidies }\end{array}$ & $\begin{array}{l}\text { Tax } \\
\text { Credit }\end{array}$ & $\begin{array}{l}\text { Import } \\
\text { Tariff } \\
\text { and } \\
\text { Charge }\end{array}$ & Total & $\begin{array}{l}\text { Differential } \\
\text { Tax Rate on } \\
\text { Hydrous } \\
\text { Ethanol }\end{array}$ & $\begin{array}{l}\text { Impact of (v) } \\
\text { on Anhydrous } \\
\text { Ethanol }\end{array}$ & Total \\
\hline & $\begin{array}{l}G_{1}^{u s} \\
(\mathrm{i})\end{array}$ & $\begin{array}{c}G_{2}^{u s} \\
\text { (ii) }\end{array}$ & $\begin{array}{l}G_{3}^{u s} \\
\text { (iii) }\end{array}$ & $\begin{array}{l}G^{u s} \\
\text { (iv) }\end{array}$ & $G_{h y d}^{b r}$ & $\begin{array}{c}G_{\text {anhyd }}^{b r} \\
\text { (vi) }\end{array}$ & $\begin{array}{l}G^{b r} \\
\text { (vii) }\end{array}$ \\
\hline 2002 & 277 & 1,156 & 1,228 & 2,661 & 221 & 354 & 574 \\
\hline 2003 & 398 & 1,515 & 1,594 & 3,506 & 199 & 372 & 571 \\
\hline 2004 & 595 & 1,839 & 1,943 & 4,376 & 360 & 500 & 861 \\
\hline 2005 & 1,463 & 1,991 & 2,278 & 5,732 & 512 & 668 & 1,180 \\
\hline 2006 & 1,167 & 2,491 & 2,931 & 6,589 & 902 & 726 & 1,628 \\
\hline 2007 & 890 & 3,326 & 3,859 & 8,075 & 1,338 & 835 & 2,173 \\
\hline 2008 & 1,274 & 4,748 & 5,574 & 11,597 & 1,576 & 737 & 2,313 \\
\hline 2009 & 1,317 & 4,922 & 6,483 & 12,722 & 1,991 & 750 & 2,742 \\
\hline 2010 & 1,410 & 6,782 & 0 & 8,192 & 3,873 & 1,933 & 5,806 \\
\hline 2011 & 1,879 & 7,114 & 0 & 8,993 & 1,999 & 1,405 & 3,404 \\
\hline 2012 & 1,134 & 0 & 0 & 1,134 & -392 & -791 & $-1,184$ \\
\hline
\end{tabular}

Notes: The following exchange rates were used to convert Brazilian real into U.S. dollar (in R\$ per US\$): $2002-2.92 ; 2003-3.08 ; 2004-2.93 ; 2005-2.44 ; 2006-2.18 ; 2007-$ 1.95 ; $2008-1.83$; $2009-1.99 ; 2010-1.76 ; 2011-1.67$ and $2012-1.95$.

Source: Authors.

removed in 2012. Subsidies on the corn used by the ethanol industry were on average US\$1 billion in 2002-12. Although the volume of corn used in ethanol production increased significantly over the last decade, total domestic support to corn fell considerably after 2005. As a result, domestic support to corn used in ethanol production remained below the 2005 level in all years except 2011. Figure 8 depicts this behavior.

U.S ethanol subsidy estimates by Koplow (2007) corroborate the values described in this study. According to this author, total subsidies to the U.S. ethanol sector reached US\$5.8-7 billion in 2006, US\$6.9-8.4 billion in 2007, US\$9.2-11 billion in 2008 and US\$11-13.4 billion in 2009. The corresponding values found in the present study were US $\$ 6.5$ billion in 2006 , US $\$ 8.0$ billion in 2007, US $\$ 11.5$ billion in 2008 and US\$12.7 billion in 2009.

Brazil's ethanol subsidy equivalent increased signifincalty over the 200211 period. While total subsidies were in the order of US\$574 million in 2002, they reached US $\$ 5.8$ billion in 2010 and US $\$ 3.4$ billion in 2011. National figures correspond to the sum of subsidy equivalents for each of the 26 Brazilian states and the federal district, which vary significantly due to differences in tax rates and consumption levels. The state of São Paulo alone accounted on average for 56\% of Brazil's ethanol subsidy equivalent in 2002-12.

The CIDE tax differential accounted for approximately $95 \%$ of the total subsidy equivalent to the Brazilian ethanol sector in 2002-03. After a number of states lowered their ICMS rates for ethanol, the share of the CIDE tax differential in the total subsidy equivalent fell to $68 \%$ in 2004-07. This share dropped even further after the reduction of the CIDE rate in 2008. The ICMS tax differential exerted its greatest influence in 2011, accounting for $50 \%$ of the total subsidy equivalent. Gasoline price controls accounted for more than $50 \%$ of the total subsidy equivalent in 2010 . 


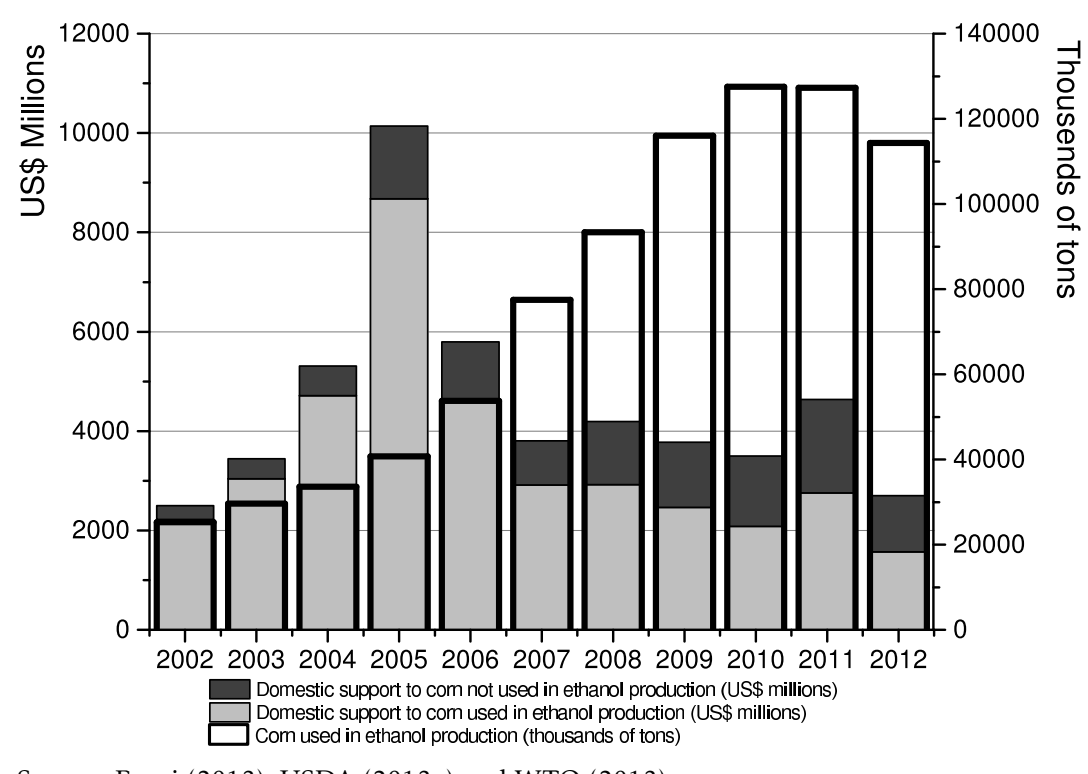

Source: Fapri (2013), USDA (2013a) and WTO (2013).

Figure 8: Volume of corn used in ethanol production and domestic support to corn and to corn used in ethanol production, United States, 200212

Another way to compare ethanol support is to consider their values relative to the value of production in each country. This approach provides a more realistic picture of the level of subsidization, especially when the countries under comparison have substantially different production volumes. In the case of Brazil and the United States, ethanol production volumes were similar between 2003 and 2005, but increasingly disparate after 2006. Notably, U.S. ethanol output was between 2 and 2.5 times higher than Brazil's between 2007 and 2012.

Figure 9 presents ethanol subsidy equivalents relative to the total value of ethanol production in the United States and Brazil. Despite the increase in overall U.S. subsidy levels between 2002 and 2011, total subsidy equivalent as a share of the production value decreased from $65 \%$ in 2002 to $17 \%$ in 2011. In Brazil, the subsidy equivalent corresponded to $14 \%$ of the value of production on average between 2002 and 2011.

In stark contrast with earlier years, and reflecting the changes in policy described in Section 2, ethanol subsidy equivalent values declined in both countries in 2012. While subsidies as a percentage of the production value dropped by $83 \%$ in the United States, they became negative in Brazil (Figure 9 and Table 3). The reversal in subsidization in Brazil was due to gasoline price controls and the elimination of the CIDE (despite the continuation of the ICMS tax differential in some states). As opposed to 2010, the government kept domestic gasoline prices below international prices in 2012. As a result, the subsidy equivalent value of Brazilian ethanol policies was US\$-1.18 billion in 2012, which correspond to $-5 \%$ of the domestic ethanol production value. 


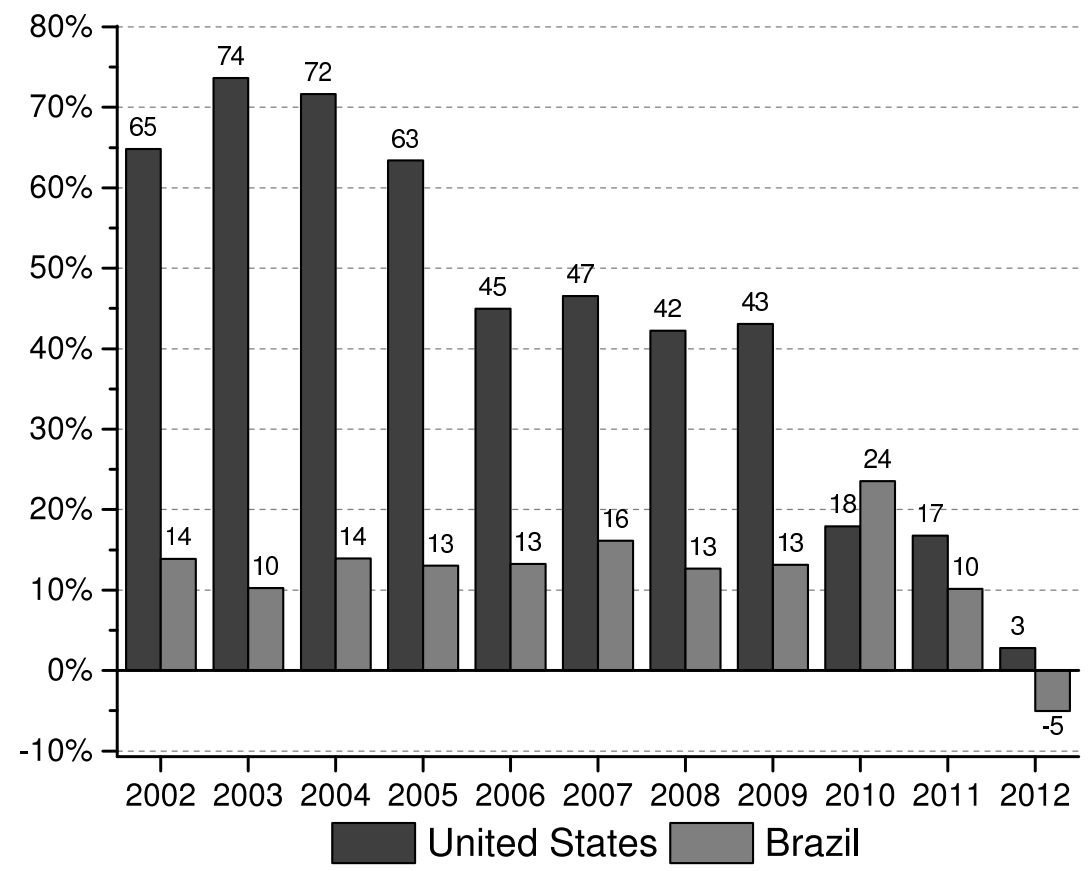

Source: Authors.

Figure 9: Share of ethanol subsidy equivalents in domestic production values, United States and Brazil, 2002-12

\section{Impacts of ethanol subsidy equivalents}

The objective of this section is to estimate the size of the market distortions caused by ethanol policies adopted in the United States and Brazil in each year of the period of 2002-12. The economic model used to estimate impacts on ethanol prices, production and consumption are described in Subsection 4.1. Results are discussed in Subsection 4.2.

\subsection{Modeling framework}

The model divides the world ethanol market into two segments: the United States and Brazil. As far as U.S. policies are concerned, this study considers only the support derived from import tariffs and the tax credit. Since the part of the subsidy equivalent value arising from the domestic support to corn production is small, it is not taken into account here. In the case of Brazil, the markets for anhydrous and hydrous ethanol are analyzed jointly. ${ }^{8}$

The modeling of the world ethanol market is based on supply and demand functions in the United States and Brazil, as these two countries were responsible for the bulk of global production and consumption in 2002-12. The model is described in equations 7 through 10 :

\footnotetext{
${ }^{8}$ Given that most producers can switch production between hydrous and anhydrous ethanol at no additional cost, price equilibrium is maintained as follows: (a) when the hydrous ethanol price is above the anhydrous ethanol price level, hydrous ethanol production is favored relative to anhydrous ethanol production. Anhydrous ethanol production falls and its price increases to the point at which an equilibrium between the two types of ethanol is reached; (b) when the hydrous ethanol price is below the anhydrous ethanol price, the opposite occurs.
} 


$$
\begin{gathered}
d \ln S^{u s}=\epsilon^{u s}\left((1-\alpha) d \ln P^{w}+\alpha d \ln g_{3}^{u s}\right) \\
d \ln S^{b r}=\epsilon^{b r} d \ln P^{w} \\
d \ln D^{u s}=\eta^{u s}\left(\left(1-\beta_{2}-\beta_{3}\right) d \ln P^{w}+\beta_{2} d \ln g_{2}^{u s}+\beta_{3} d \ln g_{3}^{u s}\right) \\
d \ln D^{b r}=\left(\gamma \eta^{b r}+(1-\gamma) \eta_{c, g}^{b r} \theta\right) d \ln P^{w}+\left(\gamma \eta_{c}^{b r}+(1-\gamma) \eta_{g}^{b r} \theta\right) d \ln P_{g}^{b r}
\end{gathered}
$$

where $S^{i}, \epsilon^{i}, D^{i}$ and $\eta^{i}$ stand for supply, supply price elasticity, demand and demand price elasticity in country $i=u s$, br. $P^{w}$ is the world ethanol price; $\alpha$ is the ratio of U.S. import tariffs to U.S. producer gross receipts, and $\beta_{2}$ and $\beta_{3}$ are the ratios of, respectively, U.S. tax credits and U.S. import tariffs to U.S. consumer final expenditures. In Section 3, subsidy equivalent values for the United States $\left(G_{2}^{u s}\right.$ and $\left.G_{3}^{u s}\right)$ were presented in monetary value. In the model presented in equations 9 through $10, g_{2}^{u s}, g_{3}^{u s}$ represent subsidy equivalent unit values. The Brazilian demand function is the weighted sum of demand functions for hydrous and anhydrous ethanol. While hydrous ethanol demand is multiplied by the share of hydrous ethanol in total ethanol fuel demanded $(\gamma)$, anhydrous ethanol demand corresponds to the demand for gasoline multiplied by the share of anhydrous ethanol in gasoline $(\theta)$ and the share of anhydrous ethanol in total ethanol fuel demanded $(1-\gamma) . P_{g}^{b r}$ is the gasoline price in Brazil, $\eta_{g}^{b r}$ is the Brazilian price elasticity of demand for gasoline, $\eta_{c, g}^{b r}$ is the Brazilian cross-price demand elasticity for gasoline with respect to ethanol, and $\eta_{c}^{b r}$ is the Brazilian cross-price demand elasticity for ethanol with respect to gasoline.

As explained in Section 2 and shown in Brazilian demand function, demand for ethanol in Brazil is also dependent on the price of gasoline. Moreover, the subsidy equivalents that were previously described in terms of ethanol production, depending on how they are disposed of, initially affect the price of gasoline in the country and then, indirectly, the price of ethanol. For example, if the differential tax between these fuels were removed, this could either increase the tax on ethanol or reduce the tax on gasoline, whereas, if gasoline price controls were eliminated, there would be only a direct effect on the price of fossil fuels. Therefore, market impacts from the elimination of ethanol support in Brazil $\left(G^{b r}\right)$ are measured by considering direct impacts on the gasoline price $\left(d \ln P_{g}^{b r}\right)$, as shown in equation 10 .

World supply $\left(S^{w}\right)$ is the sum of U.S. and Brazilian supplies:

$$
d \ln S^{w}=\delta^{u s}\left[\epsilon^{u s}\left((1-\alpha) d \ln P^{w}+\alpha d \ln g_{3}^{u s}\right)\right]+\delta^{b r} \epsilon^{b r} d \ln P^{w}
$$

where $\delta^{u s}$ and $\delta b r$ are the shares of the United States and Brazil in world ethanol production, respectively.

Similarly, world demand $\left(D^{w}\right)$ is described in equation 12 as the sum of U.S. and Brazilian demands:

$$
\begin{aligned}
d \ln D^{w}= & \phi^{u s}\left[\eta^{u s}\left(\left(1-\beta_{2}-\beta_{3}\right) d \ln P^{w}+\beta_{2} d \ln g_{2}^{u s}+\beta_{3} d \ln g_{3}^{u s}\right)\right]+ \\
& +\phi^{b r}\left[\left(\gamma \eta^{b r}+(1-\gamma) \eta_{c, g}^{b r} \theta\right) d \ln P^{w}+\left(\gamma \eta_{c}^{b r}+(1-\gamma) \eta_{g}^{b r} \theta\right) d \ln P_{g}^{b r}\right]
\end{aligned}
$$


where $\phi^{u s}$ and $\phi^{b r}$ are the shares of the United States and Brazil in world ethanol demand, respectively.

Letting world supply equal world demand and singling out $d \ln P^{w}$ :

$$
\begin{aligned}
d \ln P^{w}= & \frac{\phi^{u s} \eta^{u s} \beta_{2}}{A} d \ln g_{2}^{u s}+\frac{[\phi}{A} d \ln g_{3}^{u s}+ \\
& +\frac{\phi^{b r}\left(\gamma \eta_{c}^{b r}+(1-\gamma)-\mu_{g}^{b r} \theta\right)}{A} d \ln P_{g}^{b r}
\end{aligned}
$$

where $A=\left(\delta^{u s} \epsilon^{u s} \alpha+\delta^{b r} \epsilon^{b r}-\phi^{u s} \eta^{u s} \alpha-\phi^{b r}\left(\gamma \eta^{b r}+(1-\lambda) \eta_{c, g}^{b r} \theta\right)\right)$.

The magnitude of the impacts estimated in this study depends on the values of the parameters described in equation 13. U.S. and Brazilian shares in world ethanol production and consumption were obtained from LMC (2008) and LMC (2013). Supply and demand elasticities for the United St tes were calculated as the simple averages of the elasticities estimated by Elobeid \& Tokgoz (2008) and Luchansky \& Monks (2009). While the former tudy uses U.S. supply and demand elasticities of respectively 0.65 and -0.43 the latter estimates elasticities of 0.224 and -2.915 . Therefore, the U.S. pri e elasticities of supply and demand used in this study were 0.437 and -1.6725 , respectively.

The Brazilian supply elasticity of 1.94 was obtained in Costa et al. (2013a). Given that the change in the profile of Brazil's automobile fleet in 2002-12 radically changed the behavior of consumers, the Brazilian price-elasticity of demand is assumed to vary throughout the period. While a demand elasticity of -1.23 (Farina et al. 2010) is used for 2002, an elasticity of -3.25 is used for 2012 (Costa et al. 2013b). For 2003-11, a linear trend is assumed between the demand elasticities for 2002 and 2012. Demand cross-price elasticities for ethanol also vary between 1.45 in 2002 (Farina et al. 2010) and 2.68 in 2012 (Costa et al. 2013a). Demand price and cross-price elasticities for gasoline in Brazil of -1.08 and 0.44 are obtained from Costa et al. (2013a).

Five alternative scenarios are considered in this study. Each scenario presupposes the elimination of a different set of ethanol support policies: U.S. and Brazilian policies (Scenario 1), U.S. policies (Scenario 2), U.S. import tariffs alone (Scenario 3), U.S. tax credits alone (Scenario 4) and the Brazilian policies (Scenario 5).

\subsection{Results}

Estimated market impacts due to the elimination of U.S. and Brazilian ethanol support are summarized in Table 4 (relative effects) and Table 5 (absolute effects). Results for the 2002-11 period are analyzed separately from results for 2012, as key ethanol support policies were discontinued in January 2012 in the United States and June 2012 in Brazil.

The joint removal of U.S. and Brazilian subsidies (Scenario 1) has a minor impact on ethanol prices in 2002-11, but significantly reduces production in the United States and consumption in Brazil. Domestic ethanol prices fall on average by $0.3 \%$ in the United States and $0.9 \%$ in Brazil. While lower prices lead to an average increase of $0.9 \%$ in U.S. consumption, Brazilian consumption declines by $16.7 \%$. Ethanol output decreases on average by $1.7 \%$ in Brazil and $9.5 \%$ in the United States. 
Table 4: Relative price, production and consumption effects from the hypothetical elimination of U.S. and Brazilian ethanol support, 2002-12

\begin{tabular}{|c|c|c|c|c|c|c|c|c|c|c|c|c|}
\hline & & 2002 & 2003 & 2004 & 2005 & 2006 & 2007 & 2008 & 2009 & 2010 & 2011 & 2012 \\
\hline & & \multicolumn{11}{|c|}{ Relative Impact on Fuel Ethanol Prices } \\
\hline \multirow{5}{*}{ United States ${ }^{*}$} & Scenario 1 & $-1.1 \%$ & $1.2 \%$ & $0.4 \%$ & $-1.2 \%$ & $-2.2 \%$ & $-2.5 \%$ & $-1.5 \%$ & $-3.3 \%$ & $1.9 \%$ & $5.0 \%$ & $2.5 \%$ \\
\hline & Scenario 2 & $1.7 \%$ & $3.7 \%$ & $3.5 \%$ & $1.6 \%$ & $0.8 \%$ & $1.4 \%$ & $1.5 \%$ & $0.5 \%$ & $7.9 \%$ & $6.9 \%$ & $0.0 \%$ \\
\hline & Scenario 3 & $-15.2 \%$ & $-13.7 \%$ & $-13.1 \%$ & $-10.6 \%$ & $-8.5 \%$ & $-9.3 \%$ & $-7.9 \%$ & $-8.9 \%$ & $0.0 \%$ & $0.0 \%$ & $0.0 \%$ \\
\hline & Scenario 4 & $16.8 \%$ & $17.2 \%$ & $16.5 \%$ & $12.1 \%$ & $9.3 \%$ & $10.6 \%$ & $9.4 \%$ & $9.3 \%$ & $7.9 \%$ & $6.9 \%$ & $0.0 \%$ \\
\hline & Scenario 5 & $-2.2 \%$ & $-1.8 \%$ & $-2.3 \%$ & $-2.2 \%$ & $-2.5 \%$ & $-3.2 \%$ & $-2.4 \%$ & $-3.1 \%$ & $-5.7 \%$ & $-1.8 \%$ & $2.5 \%$ \\
\hline \multirow{6}{*}{ Brazil } & Scenario 1 & $0.6 \%$ & $2.9 \%$ & $2.1 \%$ & $1.9 \%$ & $0.8 \%$ & $0.5 \%$ & $1.5 \%$ & $2.0 \%$ & $-12.9 \%$ & $-8.2 \%$ & $2.5 \%$ \\
\hline & Scenario 2 & $3.5 \%$ & $5.4 \%$ & $5.2 \%$ & $4.8 \%$ & $3.8 \%$ & $4.5 \%$ & $4.5 \%$ & $5.8 \%$ & $-6.9 \%$ & $-6.4 \%$ & $0.0 \%$ \\
\hline & Scenario 3 & $14.7 \%$ & $19.8 \%$ & $18.7 \%$ & $14.6 \%$ & $11.5 \%$ & $12.9 \%$ & $12.4 \%$ & $13.1 \%$ & $0.0 \%$ & $0.0 \%$ & $0.0 \%$ \\
\hline & Scenario 4 & $-11.3 \%$ & $-14.6 \%$ & $-13.6 \%$ & $-9.9 \%$ & $-7.7 \%$ & $-8.5 \%$ & $-7.9 \%$ & $-7.3 \%$ & $-6.9 \%$ & $-6.4 \%$ & $0.0 \%$ \\
\hline & Scenario 5 & $-2.2 \%$ & $-1.8 \%$ & $-2.3 \%$ & $-2.2 \%$ & $-2.5 \%$ & $-3.2 \%$ & $-2.4 \%$ & $-3.1 \%$ & $-5.7 \%$ & $-1.8 \%$ & $2.5 \%$ \\
\hline & & \multicolumn{11}{|c|}{ Relative Impact on Fuel Ethanol Production } \\
\hline & Scenario 1 & $-12.9 \%$ & $-13.8 \%$ & $-13.3 \%$ & $-10.4 \%$ & $-8.5 \%$ & $-9.5 \%$ & $-8.3 \%$ & $-8.9 \%$ & $-5.7 \%$ & $-3.6 \%$ & $1.1 \%$ \\
\hline & Scenario 2 & $-12.0 \%$ & $-13.1 \%$ & $-12.3 \%$ & $-9.4 \%$ & $-7.4 \%$ & $-8.2 \%$ & $-7.3 \%$ & $-7.6 \%$ & $-3.0 \%$ & $-2.8 \%$ & $0.0 \%$ \\
\hline United States* & Scenario 3 & $-8.6 \%$ & $-8.9 \%$ & $-8.3 \%$ & $-6.2 \%$ & $-4.7 \%$ & $-5.3 \%$ & $-4.6 \%$ & $-5.1 \%$ & $0.0 \%$ & $0.0 \%$ & $0.0 \%$ \\
\hline & Scenario 4 & $-5.0 \%$ & $-6.4 \%$ & $-6.0 \%$ & $-4.3 \%$ & $-3.4 \%$ & $-3.7 \%$ & $-3.5 \%$ & $-3.2 \%$ & $-3.0 \%$ & $-2.8 \%$ & $0.0 \%$ \\
\hline & Scenario 5 & $-1.0 \%$ & $-0.8 \%$ & $-1.0 \%$ & $-1.0 \%$ & $-1.1 \%$ & $-1.4 \%$ & $-1.1 \%$ & $-1.3 \%$ & $-2.5 \%$ & $-0.8 \%$ & $1.1 \%$ \\
\hline \multirow{6}{*}{ Brazil } & Scenario 1 & $1.2 \%$ & $5.6 \%$ & $4.0 \%$ & $3.8 \%$ & $1.5 \%$ & $1.1 \%$ & $2.9 \%$ & $3.9 \%$ & $-25.1 \%$ & $-16.0 \%$ & $4.9 \%$ \\
\hline & Scenario 2 & $6.7 \%$ & $10.4 \%$ & $10.1 \%$ & $9.3 \%$ & $7.4 \%$ & $8.6 \%$ & $8.7 \%$ & $11.2 \%$ & $-13.3 \%$ & $-12.4 \%$ & $0.0 \%$ \\
\hline & Scenario 3 & $28.6 \%$ & $38.4 \%$ & $36.3 \%$ & $28.4 \%$ & $22.3 \%$ & $25.1 \%$ & $24.0 \%$ & $25.4 \%$ & $0.0 \%$ & $0.0 \%$ & $0.0 \%$ \\
\hline & Scenario 4 & $-22.0 \%$ & $-28.3 \%$ & $-26.4 \%$ & $-19.3 \%$ & $-15.0 \%$ & $-16.6 \%$ & $-15.4 \%$ & $-14.2 \%$ & $-13.3 \%$ & $-12.4 \%$ & $0.0 \%$ \\
\hline & Scenario 5 & $-4.2 \%$ & $-3.4 \%$ & $-4.4 \%$ & $-4.3 \%$ & $-4.9 \%$ & $-6.1 \%$ & $-4.7 \%$ & $-6.0 \%$ & $-11.0 \%$ & $-3.4 \%$ & $4.9 \%$ \\
\hline & & \multicolumn{11}{|c|}{ Relative Impact on Fuel Ethanol Consumption } \\
\hline \multirow{5}{*}{ United States* } & Scenario 1 & $2.8 \%$ & $1.2 \%$ & $1.6 \%$ & $3.8 \%$ & $4.4 \%$ & $4.5 \%$ & $3.2 \%$ & $6.2 \%$ & $-6.5 \%$ & $-12.3 \%$ & $-4.4 \%$ \\
\hline & Scenario 2 & $0.6 \%$ & $-0.4 \%$ & $-0.5 \%$ & $1.1 \%$ & $1.0 \%$ & $0.8 \%$ & $0.3 \%$ & $2.7 \%$ & $-15.5 \%$ & $-15.6 \%$ & $0.0 \%$ \\
\hline & Scenario 3 & $36.1 \%$ & $37.8 \%$ & $32.8 \%$ & $25.3 \%$ & $19.0 \%$ & $19.9 \%$ & $16.0 \%$ & $18.0 \%$ & $0.0 \%$ & $0.0 \%$ & $0.0 \%$ \\
\hline & Scenario 4 & $-36.9 \%$ & $-40.7 \%$ & $-35.4 \%$ & $-25.4 \%$ & $-18.6 \%$ & $-20.1 \%$ & $-16.5 \%$ & $-16.2 \%$ & $-15.5 \%$ & $-15.6 \%$ & $0.0 \%$ \\
\hline & Scenario 5 & $4.0 \%$ & $3.3 \%$ & $3.9 \%$ & $3.9 \%$ & $4.4 \%$ & $5.2 \%$ & $3.7 \%$ & $4.7 \%$ & $9.8 \%$ & $3.5 \%$ & $-4.4 \%$ \\
\hline \multirow{5}{*}{ Brazil } & Scenario 1 & $-13.2 \%$ & $-12.0 \%$ & $-14.2 \%$ & $-15.9 \%$ & $-20.5 \%$ & $-22.0 \%$ & $-18.5 \%$ & $-24.5 \%$ & $-24.0 \%$ & $-2.5 \%$ & $21.2 \%$ \\
\hline & Scenario 2 & $-1.8 \%$ & $-2.9 \%$ & $-3.5 \%$ & $-3.9 \%$ & $-4.4 \%$ & $-5.8 \%$ & $-6.7 \%$ & $-10.0 \%$ & $13.5 \%$ & $12.9 \%$ & $0.0 \%$ \\
\hline & Scenario 3 & $-7.6 \%$ & $-10.9 \%$ & $-12.6 \%$ & $-12.0 \%$ & $-13.3 \%$ & $-17.0 \%$ & $-18.4 \%$ & $-22.5 \%$ & $0.0 \%$ & $0.0 \%$ & $0.0 \%$ \\
\hline & Scenario 4 & $5.8 \%$ & $8.0 \%$ & $9.2 \%$ & $8.1 \%$ & $9.0 \%$ & $11.2 \%$ & $11.8 \%$ & $12.6 \%$ & $13.5 \%$ & $12.9 \%$ & $0.0 \%$ \\
\hline & Scenario 5 & $-11.7 \%$ & $-9.5 \%$ & $-11.3 \%$ & $-12.5 \%$ & $-16.7 \%$ & $-17.2 \%$ & $-12.6 \%$ & $-15.8 \%$ & $-38.3 \%$ & $-15.7 \%$ & $21.2 \%$ \\
\hline
\end{tabular}

Notes: ${ }^{*}$ Domestic support for corn production not considered.

Scenario 1: Elimination of U.S. and Brazilian ethanol support.

Scenario 2: Elimination of U.S. ethanol support.

Scenario 3: Elimination of U.S. import tariffs only.

Scenario 4: Elimination of U.S. tax credits only.

Scenario 5: Elimination of Brazilian ethanol support. 
Table 5: Absolute price, production and consumption effects from the hypothetical elimination of U.S. and Brazilian ethanol support, 2002-12

\begin{tabular}{|c|c|c|c|c|c|c|c|c|c|c|c|c|}
\hline & & 2002 & 2003 & 2004 & 2005 & 2006 & 2007 & 2008 & 2009 & 2010 & 2011 & 2012 \\
\hline & & \multicolumn{11}{|c|}{ Absolute Impact on Fuel Ethanol Production (million liters) } \\
\hline \multirow{5}{*}{ United States* } & Scenario 1 & $-1,044$ & $-1,464$ & $-1,712$ & $-1,534$ & $-1,566$ & $-2,353$ & $-2,941$ & $-3,691$ & $-2,849$ & $-1,904$ & 552 \\
\hline & Scenario 2 & -973 & $-1,387$ & $-1,591$ & $-1,397$ & $-1,369$ & $-2,025$ & $-2,576$ & $-3,156$ & $-1,512$ & $-1,471$ & 0 \\
\hline & Scenario 3 & -693 & -941 & $-1,073$ & -920 & -872 & $-1,314$ & $-1,610$ & $-2,127$ & 0 & 0 & 0 \\
\hline & Scenario 4 & -401 & -678 & -767 & -642 & -624 & -921 & $-1,219$ & $-1,329$ & $-1,512$ & $-1,471$ & 0 \\
\hline & Scenario 5 & -78 & -82 & -128 & -143 & -204 & -340 & -374 & -558 & $-1,251$ & -406 & 552 \\
\hline \multirow{6}{*}{ Brazil } & Scenario 1 & 154 & 591 & 461 & 475 & 218 & 163 & 467 & 690 & $-5,647$ & $-4,403$ & 1,019 \\
\hline & Scenario 2 & 873 & 1,102 & 1,166 & 1,169 & 1,096 & 1,332 & 1,387 & 1,993 & $-2,997$ & $-3,403$ & 0 \\
\hline & Scenario 3 & 3,722 & 4,072 & 4,183 & 3,585 & 3,305 & 3,869 & 3,820 & 4,505 & 0 & 0 & 0 \\
\hline & Scenario 4 & $-2,864$ & $-3,002$ & $-3,047$ & $-2,433$ & $-2,219$ & $-2,552$ & $-2,447$ & $-2,531$ & $-2,997$ & $-3,403$ & 0 \\
\hline & Scenario 5 & -553 & -361 & -509 & -543 & -724 & -943 & -751 & $-1,063$ & $-2,479$ & -940 & 1,019 \\
\hline & & \multicolumn{11}{|c|}{ Absolute Impact on Fuel Ethanol Consumption (million liters) } \\
\hline \multirow{5}{*}{ United States* } & Scenario 1 & 283 & 132 & 213 & 587 & 913 & 1,161 & 1,148 & 2,594 & $-3,170$ & $-5,818$ & $-2,202$ \\
\hline & Scenario 2 & 57 & -40 & -65 & 177 & 216 & 195 & 117 & 1,110 & $-7,495$ & $-7,368$ & 0 \\
\hline & Scenario 3 & 3,703 & 4,040 & 4,406 & 3,906 & 3,908 & 5,135 & 5,808 & 7,517 & 0 & 0 & 0 \\
\hline & Scenario 4 & $-3,784$ & $-4,350$ & $-4,758$ & $-3,917$ & $-3,833$ & $-5,173$ & $-5,970$ & $-6,747$ & $-7,495$ & $-7,368$ & 0 \\
\hline & Scenario 5 & 414 & 350 & 526 & 608 & 913 & 1,330 & 1,350 & 1,974 & 4,751 & 1,680 & $-2,202$ \\
\hline \multirow{5}{*}{ Brazil } & Scenario 1 & $-1,173$ & $-1,006$ & $-1,464$ & $-1,646$ & $-2,262$ & $-3,352$ & $-3,622$ & $-5,595$ & $-5,325$ & -489 & 3,774 \\
\hline & Scenario 2 & -158 & -246 & -361 & -405 & -489 & -888 & $-1,306$ & $-2,273$ & 2,985 & 2,493 & 0 \\
\hline & Scenario 3 & -674 & -909 & $-1,295$ & $-1,240$ & $-1,475$ & $-2,579$ & $-3,597$ & $-5,139$ & 0 & 0 & 0 \\
\hline & Scenario 4 & 519 & 670 & 944 & 842 & 990 & 1,701 & 2,304 & 2,887 & 2,985 & 2,493 & 0 \\
\hline & Scenario 5 & $-1,045$ & -793 & $-1,164$ & $-1,294$ & $-1,841$ & $-2,614$ & $-2,475$ & $-3,595$ & $-8,480$ & $-3,027$ & 3,774 \\
\hline
\end{tabular}

Notes: ${ }^{\star}$ Domestic support for corn production not considered.

Scenario 1: Elimination of U.S. and Brazilian ethanol support.

Scenario 2: Elimination of U.S. ethanol support.

Scenario 3: Elimination of U.S. import tariffs only.

Scenario 4: Elimination of U.S. tax credits only.

Scenario 5: Elimination of Brazilian ethanol support. 
The elimination of U.S. support alone (Scenario 2) increases U.S. and Brazilian ethanol prices on average by $2.4 \%$ and $3 \%$, respectively, in 2002-11. Production decreases by $8.3 \%$ in the United States, but increases by $4.7 \%$ in Brazil. ${ }^{9}$ Consumption levels fall by $2.5 \%$ in the former and $1.3 \%$ in the latter. However, 2002-11 averages for Brazil hide significant intra-period variation: while production expands on average by $9.1 \%$ in $2002-09$, it falls by $12.9 \%$ in 2010-11. Similarly, Brazilian consumption declines on average by $4.9 \%$ in $2002-09$ and rises by $13.2 \%$ in $2010-11$. Brazilian output increases and consumption falls in 2002-09 because the effects from eliminating U.S. import tariffs overshadow those from removing U.S. tax credits. The situation is reversed in 2010-11, as U.S. market price support is null in this sub-period.

The removal of U.S. import tariffs alone (Scenario 3) reduces U.S. ethanol prices on average by $8.7 \%$ in $2002-11$, which leads to an average increase of $20.5 \%$ in U.S. consumption. The elimination of U.S. tax credits alone (Scenario 4) generates diametrically opposite results: U.S. ethanol prices increase on average by $11.6 \%$ and domestic consumption decreases by $24.1 \%$ in the same period. U.S. production decreases in both scenarios $(5.2 \%$ in Scenario 3 and $4.1 \%$ in Scenario). In Brazil, prices rise by $11.8 \%$, consumption decreases on average by $11.4 \%$ and production increases by $22.8 \%$ in Scenario 3. Results for the Brazilian ethanol market in Scenario 4 are the inverse: prices fall by $9.4 \%$, consumption increases by $10.2 \%$ and production decreases by $18.3 \%$.

The greatest absolute changes in production and consumption volumes in Scenario 3 occur in 2009, when Brazilian ethanol production increase by 4.5 billion liters and U.S. consumption increases by 7.5 billion liters. In Scenario 4, the greatest absolute changes occur between 2009 and 2011: Brazilian production decreases by 3.4 billion liters in 2010 and U.S. consumption falls by 7.5 billion liters in 2009 .

The elimination of Brazil's ethanol support alone (Scenario 5) leads to an average reduction of $2.7 \%$ in ethanol prices in both countries in 2002-11. Production volumes in the United States and Brazil fall on average by $1.2 \%$ and $5.3 \%$ in the same period. While U.S. consumption increases by $4.7 \%$, Brazilian consumption declines by $16.1 \%$, as the average reduction in domestic gasoline prices $(19.3 \%)$ is considerably greater than the decline in ethanol prices. The most pronounced market changes in Scenario 5 occur in 2010, the year with the greatest mark-up in Brazilian gasoline prices relative to the international market: Brazilian ethanol price, production and consumption levels undergo retractions of respectively $5.7 \%, 11.0 \%$ and $38.3 \%$, which are more than twice as great as the average reductions for the 2002-11 period as whole.

As the domestic gasoline price in Brazil was kept below the world price in 2012 , the direction of market changes implied by Scenario 5 in this particular year is the opposite of that for 2002-11: Brazilian ethanol price, production and consumption levels increase by $2.5 \%, 4.9 \%$ and $21.2 \%$, respectively. While U.S. policies depressed world ethanol prices in 2002-11, Brazilian policies were responsible for constraining prices in 2012. As a result, Brazil's gasoline price controls adversely affected ethanol production domestically and in the United States in 2012.

Considering the results reported above for the five alternative policy reform scenarios, most distortions in ethanol markets in 2002-11 can be traced

\footnotetext{
${ }^{9}$ Output expansion is dependent on area availability. This potential limitation is not addressed in this study.
} 
back to measures applied by the United States. While U.S. policies decreased world prices and adversely affected Brazilian production in 2002-09 (Scenario 2), Brazilian policies led to higher international prices and boosted production in both countries in 2002-11 (Scenario 5). Artificially low Brazilian gasoline prices in 2012 negatively affected ethanol prices and production both domestically and in the United States. Nonetheless, the deleterious effects of Brazilian gasoline price controls on ethanol output in 2012 were greater domestically (4.9\% retraction) than in the United States (1.1\% reduction).

Among the five scenarios analyzed above, the elimination of U.S. ethanol import tariffs (Scenario 3) has by far the greatest impact on world prices (average increase of $11.8 \%$ in 2002-11). In addition, the elimination of U.S. ethanol tariffs could generate positive environmental effects. While corn ethanol production would on average decrease by $5.2 \%$ in $2002-11$, sugarcane ethanol output would increase by $22.8 \%$ in the same period. Lifecycle analyses indicate that ethanol derived from sugarcane reduces greenhouse gas emissions by $90 \%$ relative to conventional gasoline, while the reduction for ethanol derived from corn is of only 10-30\% (IEA 2009). Moreover, Brazilian sugarcane ethanol is more productive than U.S. corn ethanol in terms of liters per hectare planted. While one hectare of sugarcane in Brazil yields 6,800 liters of ethanol, one hectare of corn in the United States yields only 3,100 liters. Furthermore, the energy balance of Brazilian sugarcane ethanol is five times as high as that of U.S. corn ethanol (Worldwatch Institute 2006). Consequently, the elimination of U.S. import tariffs and additional charges would generate environmental benefits due to the replacement of corn ethanol by sugarcane ethanol.

Given the elimination of significant U.S. and Brazilian ethanol policies in 2012 , it is possible to test the model used in this study by comparing estimated market changes with actual observed variations between 2011 and 2012. Estimated and observed ethanol price, production and consumption changes are depicted in Figure 10. Estimated changes correspond to the results from the elimination of U.S. and Brazilian policies (Scenario 1) in 2011 inus the shock from eliminating the policies that remained in place in 2012.

While estimated price, production and consumption relative changes in the United States were respectively $2.0 \%,-3.5 \%$ and $-4.3 \%$, those actually observed were $-2.5 \%,-3.3 \%$, and $3.5 \%$. In Brazil, estimated changes were $-11.2 \%$ for the domestic price, $-6.4 \%$ for production and $-5.6 \%$ for consumption. Those observed were $-2.6 \%,-5.1 \%$ and $-2.1 \%$. Although estimated production changes followed observed changes closely, estimated and observed price and consumption changes were not as close. The differences between observed and estimated price and consumption in Brazil can be explained by the domestic sugarcane crop failure. Two factors may have contributed to the difference between estimated and observed price changes in the United States: the sugarcane crop failure in Brazil and expectations about the end of the tax credit in 2012. In 2011, these two factors made the U.S. domestic ethanol price increase more than expected. Demand for ethanol in the United States rose because domestic blenders increased sales to maximize the benefit from the tax credit before it expired by year's end and because Brazilian blenders to import large volumes of ethanol due to the local sugarcane crop failure. Higher observed changes in U.S. consumption as compared to estimated changes may also explained by increases in fleet and income, factors that are not considered in the present simulation. 


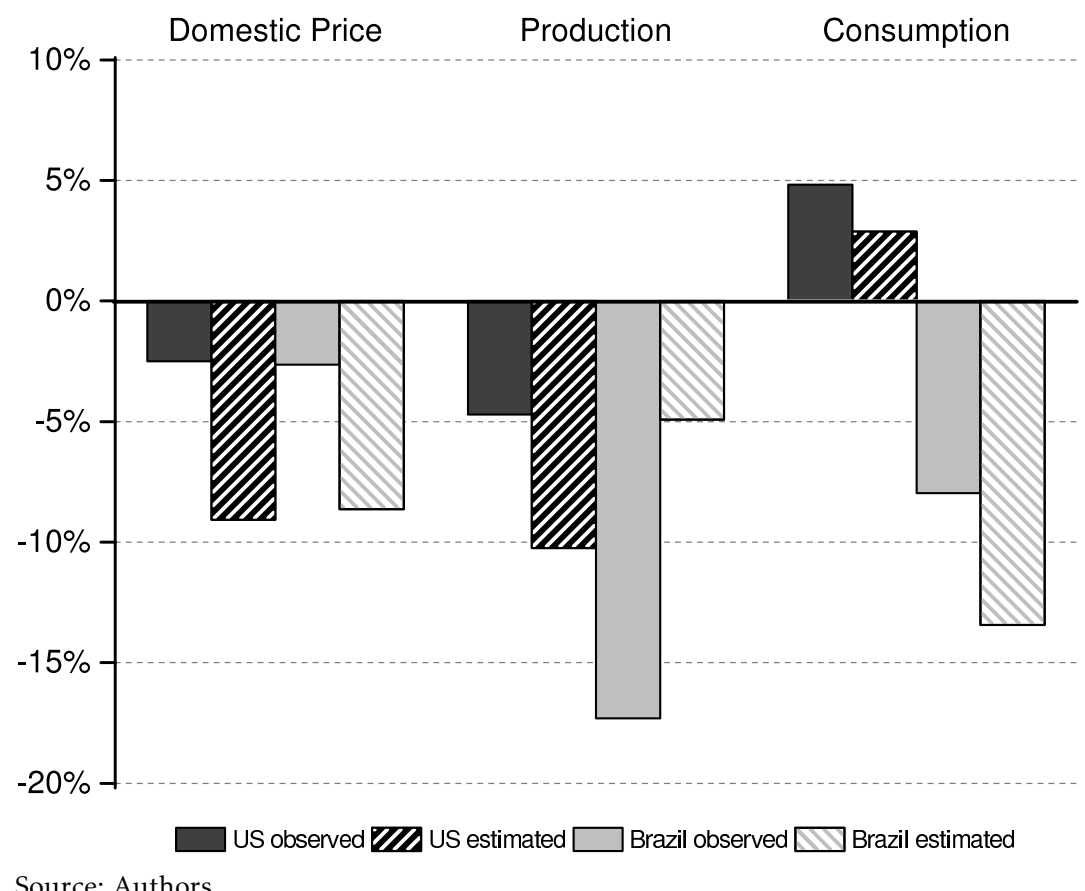

Figure 10: Observed and estimated percent changes in ethanol prices, production and consumption in the United States and Brazil, from 2011 to 2012

Small differences between estimated and observed market changes in 2012 may also be explained by limitations in the model. First, the elasticity values adopted may not exactly express the market behavior when policies changed. Second, elasticities are generally appropriate for small changes, but are not very well defined for the large changes that occurred in 2012. Finally, subsidies are not the only forces that influence producer and consumer behavior. Crop failures, economic growth and technology changes are some of these other factors. Figure 11 illustrates the results of a sensitivity analysis with four different sets of supply and demand price elasticities: (i) all elasticities are 10\% higher; (ii) all elasticities are 10\% lower; (iii) Brazilian elasticities are $10 \%$ higher and U.S. elasticities are 10\% lower; and (iv) Brazilian elasticities are $10 \%$ lower and U.S. elasticities are $10 \%$ higher. The sensitivity analysis was applied only to Scenario 1 and Scenario 5, as production and consumption effects in the other scenarios were null in 2012.

As indicated in Figure 11, estimated results vary little when elasticities are increased or decreased by $10 \%$. This sensitive analysis suggests that elasticity values are not the main source of variation between estimated and observed changes identified in Figure 10.

\section{Conclusion}

The pressing need for reductions in greenhouse gas emissions has brought increased attention to public policies that encourage the adoption of biofuels. Public and private sector representatives across the globe disagree on the 


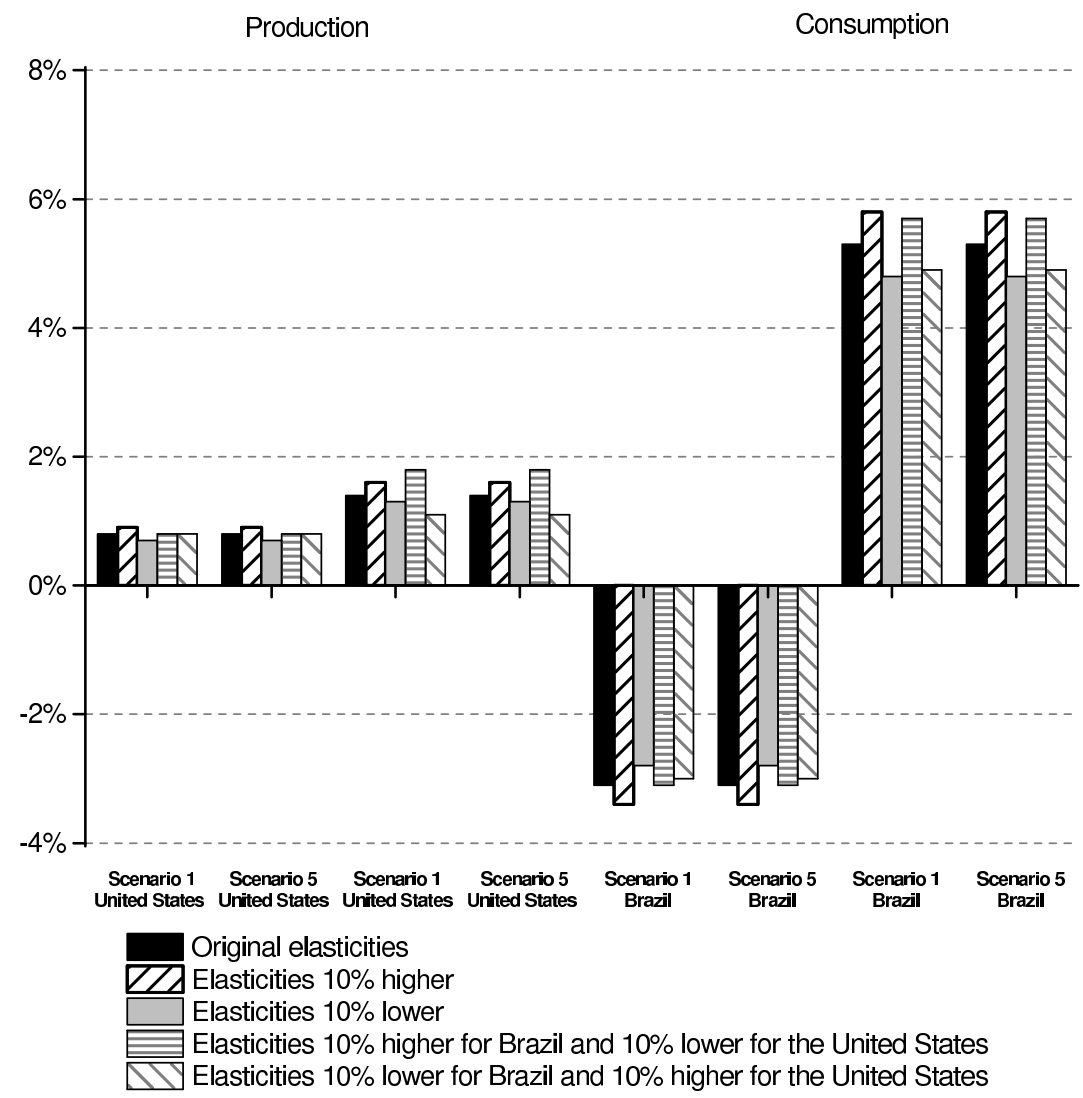

Source: Authors.

Figure 11: Estimated relative changes in production and consumption under alternative sets of elasticities, Scenarios 1 and 5, 2012

magnitude of biofuel subsidies and their market impacts. The present study contributes to this discussion by providing estimates of the subsidy equivalent values of ethanol policies in the United States and Brazil, the world's leading biofuel producers. For 2002-11, average annual ethanol subsidy levels were US\$7.2 billion in the United States and US\$2.1 billion in Brazil. These figures were equivalent to approximately $48 \%$ of the value of domestic ethanol production in the United States and 14\% in Brazil.

The study also estimates the effects of U.S. and Brazilian ethanol subsidies on prices, production and consumption. While U.S. ethanol policies provided incentives to domestic production at the expense of imports in 2002-11, Brazilian policies encouraged production without discriminating between domestic and foreign ethanol. As a result, foreign producers were adversely affected by the former, but benefited from the latter. U.S. ethanol policies depressed world prices by $2.4 \%$ on average in 2002-11, whereas Brazilian policies boosted prices by $2.7 \%$ in the same period. The negative market effects of U.S. policies were most prominent in years with high levels of market price support. For example, U.S. policies depressed world prices by $5.5-6 \%$ and curtailed Brazilian output by $10.5-11 \%$ in 2003 and 2009. Although most U.S. ethanol policy instruments were discontinued in 2012, the measurements performed in this study remain relevant due to the apprehension over the pos- 
sible reactivation of ethanol tax credits and import tariffs. Given that the ethanol blending mandate in the United States will increase from 15.2 billion gallons in 2012 to 36 billion gallons in 2022, market distortions caused by U.S. policies could significantly increase in the near future if import barriers and tax credits were reinstated. Distortions would be even larger if import tariffs were reintroduced alone.

The period examined in this study covers significant policy changes not only in the United States, but also in Brazil. Most notably, U.S. ethanol import tariffs and tax credits were eliminated in January 2012 and Brazil's CIDE tax differential was removed in June 2012. In addition, Brazilian gasoline price controls, which kept domestic prices above world prices in 2002-11, were reversed in 2012, causing Brazilian gasoline prices to be below international prices for the first time in a decade. While U.S. policies reduced ethanol production in Brazil prior to 2011, Brazilian gasoline price controls were responsible for reducing domestic ethanol output by $5 \%$ in 2012. Therefore, domestic policies became the main source of adverse effects on Brazil's ethanol market.

Biofuels provide a great possibility for the substitution of carbon-intensive fossil fuels. Brazil and the United States have championed a transformation in transportation fuel use with public policies that encourage the adoption of ethanol. However, these same policies generate distortions that may jeopardize the consolidation of an international market for ethanol. The subsidy equivalent values and market distortion estimates presented in this study provide U.S and Brazilian policymakers with vital inputs for the assessment of the multifaceted implications of ethanol support.

\section{Acknowledgments}

The authors thanks the National Center of Scientific and Technological Development (CNPq).

\section{Bibliography}

ANP (2013a), 'Dados estatísticos mensais: vendas de combustíveis'.

URL: Avaiable at http://www.anp.gov.br/petro/dados_estatisticos.asp/, Accessed in 2013-09-17

ANP (2013b), 'Levantamento de preços e de margem de comercialização de combustíveis, coordenadoria de defesa da concorrência'.

URL: Avaiable at http://www.anp.gov.br/petro/relatorios_precos.asp/, Accessed in 2013-09-02

Brazilian Ministry of Finance (2013), 'DCide (lei no. 10.336, de 19/12/2001)'.

URL: Avaiable at http://www.receita.fazenda.gov.br/PessoaJuridica/CIDEComb/, Accessed in 2013-09-17

Costa, C. C., Burnquist, H. L., Souza, M. J. P., Rodrigues, L. \& Constanza, V. (2013a), An assessment of fuel ethanol supply in Brazil from 2000 to 2011, in 'ESADR, 2013', Évora, Portugal. 
Costa, C. C., Burnquist, H. L., Souza, M. J. P., Rodrigues, L. \& Constanza, V. (2013b), Fuel demand in Brazil and consumer choice between ethanol and gasoline. Research report. Unpublished.

Costa, C. C. \& Guilhoto, J. J. M. (2011), 'O papel da tributação diferenciada dos combustíveis no desenvolvimento econômico do estado de São Paulo', Economia Aplicada 15(3), 371-392.

Elobeid, A. \& Tokgoz, S. (2008), 'Removing distortions in the U.S. ethanol market: What does it imply for the United States and Brazil?', American Journal of Agricultural Economics 90(4), 918-932.

FAO (2013), 'United Nations Commodity Trade Statistics database - COMTRADE'.

URL: Avaiable at http://comtrade.un.org/db/, Accessed in 2013-02-02

Fapri (2013), 'U.S. and world agricultural outlook database'.

URL: Avaiable at http://www.fapri.iastate.edu/tools/outlook.aspx, Accessed in 2013-05-14

Farina, E., Viegas, C., Pereda, P. \& Garcia, C. (2010), Estruturas de mercado e concorrência do setor de etanol, in E. L. Sousa \& I. C. Macedo, eds, 'Etanol e bioeletricidade: a cana-de-açúcar no futuro da matriz energética', São Paulo: Luc Projetos de Comunicação, pp. 226-259.

IEA (2009), 'CO2 Emissions from Fuel Combustion: Highlights'.

URL: Avaiable at http://www.iea.org/co2highlights/CO2highlights.pdf, Accessed in 2010-04-20

Koplow, D. (2007), 'Biofuels - at what cost? government support for ethanol and biodiesel in the United States: 2007 update'.

URL: Avaiable at http://www.globalsubsidies.org/files/assets/Brochure__US_Update.pdf, Accessed in 2009-12-10

LMC (2008), Ethanol Quarterly - 4th Quarter, 2008, Technical report, Oxford: LMC International.

LMC (2013), Ethanol Quarterly - 1st Quarter, 2013, Technical report, Oxford: LMC International.

Luchansky, M. S. \& Monks, J. (2009), 'Supply and demand elasticities in the US ethanol fuel market', Energy Economics 31(3), 403-410.

MDIC (2013), 'Ministério do Desenvolvimento, Indústria e Comércio Exterior. Comércio Exterior. Estatísticas de Comércio Exterior. Aliceweb'.

URL: Avaiable at http://aliceweb.desenvolvimento.gov.br, Accessed in 2013-0203

OECD (2008), 'OECD’s Producer Support Estimate and Related Indicators of Agricultural Support: Concepts, Calculations, Interpretation and Use (The PSE Manual)'.

State Secretariats of Finance (2013), 'Regulamento do ICMS - RICMS'. Avaiable at individual websites for each Brazilian state. Accessed in 2013-09. 
Tyner, W. E. (2008), 'The US ethanol and biofuels boom: Its origins, current status, and future prospects', BioScience 58(7), 646-653.

UNICA (2013a), 'Quotes\&Stats'.

URL: Avaiable at http://www.unica.com.br, Accessed in 2013-09-10

UNICA (2013b), 'Unicadata - Veículos automotores - Veículos — Frota'.

URL: Avaiable at http://www.unica.com.br, Accessed in 2013-03-03

USDA (2013a), 'CCC budget essentials'.

URL: Avaiable at http://www.fsa.usda.gov/FSA/webapp?area=aboutEsubject=landingEtopic=bap-bu-cc, Accessed in 2013-09-13

USDA (2013b), 'World Agricultural Supply and Demand Estimates (WASDE), World Agricultural Outlook Board (WAOB)'.

URL: Avaiable at http://www.usda.gov/oce/commodity/wasde/, Accessed in 2013$10-12$

USITC (2013), 'Interactive Tariff and Trade DataWeb'.

URL: Avaiable at http://dataweb.usitc.gov/scripts/user_set.asp, Accessed in 201309-23

Worldwatch Institute (2006), Biofuels for Transportation: Global Potential and Implications for Sustainable Agriculture and Energy in the 21st Century, Washington,D.C.

WTO (2013), 'Notification, Committee on Agriculture'. G/AG/N/USA/60. 